\title{
Fordæmi um fordæmi
}

\section{Einar Karl Hallvarðsson}

Ágrip: Í greininni er vikið að viðteknum kenningum um gildi fordæma sem réttarheimildar og hvort hún telst formlega bindandi eður ei. Gerð er grein fyrir nýlegum dómi par sem ágreiningur er um réttarframkvæmd að pví er varðar aðild ríkisins vegna dómsmála um gildi úrskurða æðri stjórnvalda. Í framhaldi af pví eru kannað lauslega hvernig Hæstiréttur hefur alla jafna vísað til fyrri fordæma og litið sérstaklega til dóma par sem dómendur virðast ekki einhuga um gildi pessarar réttarheimildar.

Lykilorð: fordæmi; Ísland; Hæstiréttur

\begin{abstract}
This article discusses several judgements by Iceland's Supreme Court which seem to reflect differing understandings of the status of judicial precedents. Despite the fact that Icelandic courts are not constitutionally or legally obligated to follow precedents, case law shows a very strong tendency to do so, as long as the circumstances are similar and the relevant laws have not changed in the meantime. However, some Supreme Court judges seem to have been willing to challenge the custom of following precedent. The article focuses on recent decisions where the Supreme Court has divided in its views on the importance of precedent.
\end{abstract}

Keywords: precedent; Iceland; Supreme Court

\section{Inngangur}

Fordæmi er ein réttarheimilda. Á pví leikur ekki vafi og sitthvað hefur verið ritað um hana. Hér er ekki ætlunin að bæta par við eða úr. Átök hafa verið um pessa réttarheimild og peim samfara eru oft deilur um hvert sé hlutverk dómstóla í mótun nýrra reglna eða öllu heldur hvort peir eigi að hafa par hlutverk. Aðrir hafa lýst pessari réttarheimild og brotið hana til mergjar. Hér er stuðst við helstu sjónarmið úr íslenskum kennslubókum og greinum.

Um hlutverk dómstóla við setningu réttarreglna og ólík sjónarmið par að lútandi má vísa í rannsóknir Sigurðar Líndal og Jóns Steinars Gunnlaugssonar. Í bók Sigurðar Um lög og lögfræði ${ }^{1}$ er sérstakur viðauki um petta efni og í riti hins síðarnefnda um fordæmi og valdmörk dómstóla er einnig um pað fjallað. ${ }^{2}$ Í skrifum peirra

1 Sigurður Líndal, Um lög og lögfræði: grundvöllur laga - réttarheimildir (Reykjavík: Hið íslenska bókmenntafélag, 2003). Hér er vísað í útgáfuna frá 2003, en í endurskoðaðri útgáfu frá 2007 eru ekki teljandi breytingar um pað efni sem borið er niður í.

2 Jón Steinar Gunnlaugsson, Um fordæmi og valdmörk dómstóla (Reykjavík: Háskólinn í Reykjavík, 2003). 
tveggja koma fram helstu meiningar og kenningar um petta efni, oft öndverð sjónarmið. Hugmyndin er ekki að takast á við höfundana um petta efni. Skoðun pess sem petta ritar, e.t.v. frekar réttarvitund, er sú að menn hljóti að sjá fyrir sér eina rétta lögfræðilega niðurstöðu um tiltekið sakarefni sem borið er undir dóm. Pað er líka skoðun pess, sem petta ritar, að dómstólar eigi ekki að leggjast sérstaklega á árarnar við lagasmíð. Раð sem vakti áhuga til pessara skrifa er að margir nýlegir dómar Hæstaréttar endurspegla pessi átök og fróðlegt er að skyggnast í pað hvernig æðsti dómstóllinn vísar í fordæmi undanfarin misseri, sérstaklega pegar dómendur eru ekki einhuga. Upphaflega var innblástur greinarinnar dómur sem Hæstiréttur felldi í kærumáli sumarið 2008. Par var til endurskoðunar hvort vísa hefði átt frá héraðsdómi kröfum í máli á hendur íslenska ríkinu. Fyrir héraðsdómi var pess krafist að felldur yrði úr gildi sá hluti úrskurðar umhverfisráðherra frá 5. janúar 2007 par sem fallist var á leið B í 2. áfanga Vestfjarðavegar (60) Bjarkarlundur - Eyri í Reykhólahreppi með skilyrðum í sex liðum. Stefnendur voru prír einstaklingar og tvenn félagasamtök. Stefndu peir íslenska ríkinu og Vegagerðinni. Dómur Hæstaréttar féll pann 18. júní 2008 í málinu nr. 264/2008.

Nokkuð hefur verið ritað um pau réttarfarslegu álitamál sem snerta varnaraðild ríkisins. Höfundur pessarar greinar setti niður á blað grein par sem tæpt var á pví efni undir heitinu „Hvernig er petta með ríkið?““3 Pá var spurt hvernig petta er með ríkið, en að gengnum dómi Hæstaréttar mætti e.t.v. frekar spyrja hvernig var petta með ríkið. Væntingar eru pá um að löggjafinn purfi að bregðast við pví hvernig nánar fari með kröfur á hendur hinu opinbera pegar úrskurður á æðsta stjórnsýslustigi er til úrlausnar. Fleiri hafa komið inn á petta efni. Má nefna greinar eftir Skúla Magnússon, ${ }^{4}$ Ólaf Jóhannes Einarsson ${ }^{5}$ og einnig hafði verið tæpt á vandamálinu í grein eftir Sigurð Tómas Magnússon. ${ }^{6}$

Dómurinn sem nefndur var afhjúpar eldri dómaframkvæmd sem er illskiljanleg og óhagkvæm í flestu tilliti að mati höfundar. Dómurinn er einnig áhugaverður sökum pess að par er tekist á um hvernig eigi að skilja tiltekin fordæmi sem rétturinn mótaði sjálfur.

Í pessari grein er pá einnig ætlunin að hreyfa við nokkrum sjónarmiðum er varða fordæmi æðsta dómstólsins. Рað kemur orðið fyrir að í dómum Hæstaréttar sést hvar dómendur eru að rýna í fordæmi réttarins sjálfs, endurskoða gildi peirra eða velja á milli einhverra fordæma til að máta við úrlausnarefni hverju sinni. Menn velta pví fyrir sér hvort fordæmi Hæstaréttar séu bindandi að óbreyttum lögum um sams konar eða hliðstætt úrlausnarefni. Fullyrðing í pá veru er almennt ekki talin

3 Einar Karl Hallvarðsson, „Hvernig er petta með ríkið?“ Úlfljótur 58 (2005), bls. 495-525.

4 Skúli Magnússon, „Er pörf á lagasetningu um aðild hins opinbera að dómsmálum?“ Úlfljótur 58 (2005), bls. 527-538.

5 Ólafur Jóhannes Einarsson, „Réttarfarsskilyrði til að fá stjórnvaldsákvörðun endurskoðaða fyrir dómi.“ Tímarit lögfræðinga 57 (2007), bls. 39-81.

6 Sigurður Tómas Magnússon, „Aðgangur að dómstólum á sviði einkamála,“ Tímarit lögfræðinga 55 (2005), bls. 144-145. 
standast fræðilega, pví bent hefur verið á í réttarheimildafræðinni að engin lög knýi Hæstarétt til að fara að fordæmum sínum. ${ }^{7}$ En pessa fullyrðingu má pó styðja við heimildir og rökstyðja lögfræðilega. Ekki parf annað til vitnis en að varpa fram peirri staðreynd hversu oft - og vafalaust oftar en áður - Hæstiréttur vísar beint í fordæmi til stuðnings niðurstöðum eða kveður á um að atvik máls séu ekki sambærileg fordæminu og pví gildi pað ekki í viðkomandi máli. Hæstiréttur er líklegur til að beita fordæminu en ætti að vera ólíklegri til að víkja frá peim. ${ }^{8}$ Pað hljóta dæmin að sýna. Nýjar víddir koma svo til par sem dómendur virðast fjalla um fyrri dóma réttarins af fræðilegri ástríðu eða á gagnrýninn hátt með pví að peir telja pau ekki standast. Og pá vaknar spurningin um pað hverjar eru hinar eiginlegu réttarheimildir og hver er rétthæð peirra pegar æðsti dómstóllinn hefur lýst hvernig fara eigi með tiltekið lagaatriði máls. Einnig verður staldrað við pá aðstöðu pegar dómari skilar sératkvæði og sambærilegt sakarefni, t.d. bara lagaatriði, kemur til kasta réttarins að nýju. Er pá rétt að hann skili sératkvæði um niðurstöðuna aftur eða telur hann sig bundinn af fordæminu og skipar sér par á bás? Ætla verður að jafnræðisregla hvetji hann til pess að dæma á sömu lund og meirihlutinn hafði gert. Petta á ekki bara við um fjölskipaðan dóm heldur einnig ýmis fjölskipuð stjórnvöld. Pegar fjölskipuð stjórnvöld eiga í hlut má leiða pessa niðurstöðu beint af jafnræðisreglu stjórnsýslulaga. Vafamál er hins vegar hvort Hæstiréttur sé bundinn af jafnræðisreglu stjórnarskrárinnar við pessar aðstæður. En af pví að dómur Hæstaréttar frá í júní 2008 lýsir nokkrum átökum um gildi fordæma og hvort fordæmin voru talin standast aðrar réttarheimildir við nánari skoðun er rétt að víkja að honum betur.

\section{Dómur Hæstaréttar frá 18. júní 2008 í málinu nr. 264/2008}

Pað er fremur sjaldgæft að dóm Hæstaréttar í kærumáli af vettvangi einkamála skipi fimm dómarar. Af eðlilegum ástæðum er hefð fyrir pví ef úrskurðum Félagsdóms er pangað skotið. Oftast skipa Hæstarétt prír dómendur pegar leyst er úr kærumálum í einkamáli. Fjöldi dómenda ræðst pó vitaskuld af reglum 7. gr. dómstólalaga nr.

15/1998. Samkvæmt pví var hér um mikilvægt úrlausnarefni að ræða. Athygli vekur pó að í pessum dómi er verið að leysa úr lagaatriði á sviði réttarfars sem nokkuð oft hefur komið við sögu áður. Vandasamt er pess vegna að fullyrða um hvað varð pess valdandi að fimm dómarar skipuðu dóminn og að honum gengnum vaknar sú spurning af hverju dómurinn príklofnaði í afstöðu sinni. Prír dómendur stóðu að dómsniðurstöðu Hæstaréttar, einn peirra pó með öðrum forsendum. Tveir skiluðu sératkvæði um aðra niðurstöðu.

Málsatvik voru í stuttu máli pau að Vegagerðin gerði sem framkvæmdaraðili drög að tillögu að matsáætlun fyrir mat á umhverfisáhrifum Vestfjarðavegar (Pórisstaðir-Eyrará í Reykhólahreppi). Voru par settir fram sex mismunandi fram-

7 Sjá nánar í kafla 3 hér á eftir.

8 Sigurður Líndal, Inngangur að lögfræði. II. Réttarheimildir: fordæmi (Bráðabirgðaútgáfa til kennslu, Reykjavík, 1996), bls. 44. 
kvæmdakostir. Skipulagsstofnun gerði margvíslegar athugasemdir við pessi drög en úrskurðaði á endanum að fallast mætti á alla valkosti Vegagerðarinnar í 1. og 3. áfanga auk leiðar D í 2. áfanga með skilyrðum. Lagðist stofnunin hins vegar gegn tveimur leiðum, B og C, vegna umtalsverðra umhverfisáhrifa. Níu aðilar kærðu úrskurðinn til umhverfisráðherra, par af tveir til staðfestingar. Umhverfisráðherra kvað upp úrskurð pann 5. janúar 2007 par sem hann féllst á leið B í 2. áfanga Vestfjarðavegar með skilyrðum andstætt niðurstöðu Skipulagsstofnunar, sem hafði fallist á leið D. Leið C var hins vegar hafnað. Stefnendur málsins, prír einstaklingar og tvenn félagasamtök, kröfðust ógildingar á úrskurði ráðherra par sem fallist var á leið B í 2. áfanga. Stefndu peir sem fyrr segir íslenska ríkinu og Vegagerðinni. Auk pess að krefjast málskostnaðar, settu stefnendur fram svohljóðandi dómkröfu:

Stefnendur krefjast pess að felldur verði úr gildi sá hluti úrskurðar fyrrverandi umhverfisráðherra, Jónínu Bjartmarz, frá 5. janúar 2007 par sem fallist er á leið B í 2. áfanga Vestfjarðavegar (60) Bjarkalundur - Eyri í Reykhólahreppi með skilyrðum í 6 liðum.

Í kærumálinu er m.ö.o. tekist á um hvort vísa ætti pessari kröfu á hendur íslenska ríkinu frá dómi. Ekki var deilt um að Vegagerðin væri réttilega að málsókninni komin. Rétt er að nefna strax að stefnendur byggðu meðal annars á pví að með úrskurði sínum hefði umhverfisráðherra ekki uppfyllt skilyrði ákvæða stjórnsýslulaga nr. 37/1993 um rannsókn máls, ekki gætt meðalhófs og par að auki brotið gegn 13. og 14. gr. laganna. Petta hefur töluverða pýðingu pegar virt er hvort réttlætanlegt var að stefna íslenska ríkinu. Vandamálið snýst m.ö.o. um pá dómvenju sem virðist hafa skapast um að ekki standi réttarfarsnauðsyn til pess að stefna æðra stjórnvaldi til ógildingar á úrskurði pess í kærumáli og hvort sú dómvenja sé skýr, en óljóst er á hvaða réttarheimild dómstólar byggðu pessa próun á.

\section{1. Úrskurður héraðsdóms}

Héraðsdómur vísaði frá kröfum á hendur íslenska ríkinu og studdi pá niðurstöðu við fordæmi Hæstaréttar, einkum hrd. 1997, bls. 2856 og 2918, hrd. 2001, bls. 4620 (431/2001) og hrd. 2002, bls. 3910 (501/2002). Nánar sagði um pessi fordæmi í úrskurði héraðsdóms:

Fordæmin eru pess efnis að vísa beri frá kröfum á hendur æðra stjórnvaldi, ef um æðra stjórnvald á málskotsstigi innan stjórnsýslunnar er að ræða, par sem hið æðra setta stjórnvald hafi pá ekki lögvarða hagsmuni af úrlausn málsins og ekki sé fyrir hendi réttarfarsnauðsyn á að gefa pví kost á að láta til sín taka dómsmál sem eingöngu er höfðað til niðurfellingar á stjórnvaldsákvörðun pess.

Jafnvel pótt fallist sé á með stefnendum að svo virðist sem ákveðin réttarpróun hafi orðið í pá átt sem stefnendur hafa haldið fram, eru fordæmi pau sem stefnendur vísuðu til í sínum málflutningi ekki jafn fortakslaus og peir dómar sem stefndi vísar til. Í ljósi hinna skýru fordæma Hæstaréttar um aðild æðra setts stjórnvalds í málum sem eru sambærileg máli pessu, er pví óhjákvæmileg niðurstaða dómsins að umhverfisráðherra, sem í máli pessu gegndi hlutverki æðra stjórnvalds á málskotsstigi innan stjórnsýslunnar, sbr. 26. gr. stjórnsýslulaga nr. 37/1993, hafi ekki lögvarða hagsmuni af úrlausn málsins sem 
leitt geti til aðildar hans að pví. Pá verður heldur ekki talið að réttarfarsnauðsyn sé á pví að gefa ráðherranum kost á að láta til sín taka mál petta, sem eingöngu er höfðað til ógildingar á hluta úrskurðar hans.

Um niðurstöðu pessa efnis, sem héraðsdómur var sjálfsagt knúinn til að leggja til grundvallar í ljósi fordæma, hefur verið rætt og ritað sem fyrr segir. Bent hefur verið á að niðurstaða í pessa veru er óvenjuleg og á tíðum illskiljanleg, bæði út frá reglum einkamálaréttarfars og stjórnsýsluréttar. Skortur á lögvörðum hagsmunum er hindrun fyrir pá sem höfða mál, sbr. 2. mgr. 25. gr. laga nr. 91/1991 og meginreglur par að lútandi, en óvenjulegt er að varnaraðili geti flúið málaferli með pví að telja sig ekki eiga hagsmuni af úrlausninni. Hagsmunaskortur stefnda, ef svo mætti kalla, felst fremur í pví að hann eða peir eiga ekki aðild að máli eða að umkrafin skylda (eða viðurkenning á réttindum stefnanda) hvílir einfaldlega ekki á peim pótt ekkert sé við aðildina að athuga. Frá sjónarhóli stjórnsýsluréttar er pessi dómaframkvæmd einnig óvenjuleg pví dómstólar hafa almennt lagt áherslu á að pví stjórnvaldi beri að stefna sem tekið hafi pá ákvörðun sem um er deilt. Dómaframkvæmdin sýnir líka að ekki virðist ráða úrslitum hvort um var að ræða úrskurðaraðila á æðra stigi stjórnsýslu eða ekki. Pannig er mjög erfitt að greina hvenær frávísun á við og hvenær ekki. рað er líka sérkennilegt að telja ekki réttarfarsnauðsyn á pví að gefa ráðherra kost á að láta mál til sín taka „sem eingöngu er höfðað til ógildingar á hluta úrskurðar hans“. Hljómar pað ekki eins og að segja að ekki sé réttarfarsnauðsyn á að gefa móður kost á að láta til sín taka mál sem eingöngu er höfðað til að fá úr pví skorið hvort hún verði svipt forræði yfir barni sínu?

\subsection{Dómur Hæstaréttar}

Með dómi Hæstaréttar var hinn kærði úrskurður staðfestur. Dómurinn vekur upp pá spurningu af hverju ekki var vísað til forsendna héraðsdóms og úrskurður hans með pví staðfestur ágreiningslaust meðal dómenda. Fyrr er gefið í skyn að niðurstaða héraðsdóms var sennilegast óhjákvæmileg í ljósi fordæma. Eins og úrskurðurinn ber með sér var dómaranum í héraði pó vandi á höndum pví fordæmin voru ekki á eina lund. Málið átti pó sterka samstöðu með peim fyrri par sem vísað hafði verið frá kröfum á hendur íslenska ríkinu. En purfti meirihlutinn að byggja niðurstöðu sína á öðru en fyrri fordæmum eða t.d. að vísa til „dómaframkvæmdar“. Af hverju taldi meirihlutinn rétt að orða forsendur með öðrum hætti en fyrr hafði verið gert?

Í atkvæði tveggja dómenda, sem myndaði ásamt einum öðrum dómara niðurstöðu Hæstaréttar, sagði:

Úrskurður umhverfisráðherra, sem mál petta er höfðað um, felur í sér heimild handa varnaraðilanum Vegagerðinni til nánar tiltekinnar framkvæmdar. Óhjákvæmilegt er pví að beina máli um ógildingu úrskurðarins að pessum varnaraðila. Pegar metið er hvort sóknaraðilum sé nauðsynlegt eða heimilt að beina dómkröfum sínum jafnframt að varnaraðilanum íslenska ríkinu verður að gæta að pví að milli hans og varnaraðilans Vegagerðarinnar er ekkert réttarsamband, sem leitt getur af sér óskipt réttindi peirra eða óskipta skyldu gagnvart sóknaraðilum. Sameiginleg aðild peirra til varnar í málinu 
verður pví ekki studd við ákvæði 1. mgr. 18. gr. laga nr. 91/1991. Í 1. mgr. 19. gr. sömu laga er peim, sem höfðar einkamál, heimilað að sækja par tvær eða fleiri kröfur sínar á hendur tveimur eða fleiri aðilum ef kröfurnar eiga rætur að rekja til sama atviks, aðstöðu eða löggernings. Ákvæði petta er sett til hagræðis fyrir stefnanda máls og hefur aðeins að geyma heimild, sem óskylt er að neyta, enda verður máli aldrei vísað frá dómi fyrir pær sakir að stefnandi láti petta hjá líða. Í máli pví, sem hér er til úrlausnar, getur ekki komið til kasta pessa lagaákvæðis, enda gætu sóknaraðilar aldrei talist eiga sjálfstæða kröfu á hendur hvorum varnaraðila um ógildingu úrskurðar umhverfisráðherra, sem peim væri í sjálfsvald sett hvort sótt yrði í einu dómsmáli eða tveimur. Að pessum kostum frágengnum gæti aðild varnaraðilans íslenska ríkisins að málinu ekki komið til álita nema eftir ákvæðum 21. gr. laga nr. 91/1991, en pá leið hafa sóknaraðilar ekki kosið að fara. Ekki er unnt að fallast á að sóknaraðilum sé heimilt að beina kröfum sínum að pessum tveimur varnaraðilum án pess að fyrir pví sé lagastoð, enda er hvergi í réttarfarslögum að finna fyrirmæli um hvernig standa ætti að rekstri máls við pær aðstæður, meðal annars ef varnaraðilarnir létu ekki málið báðir til sín taka, gerðu par ólíkar dómkröfur eða bæru fyrir sig mismunandi málsástæður. Samkvæmt pessu verður hinn kærði úrskurður staðfestur.

Ekki er unnt að greina neinar breytingar á lögum sem knúðu Hæstarétt til að gefa vandamálinu pennan sérstaka gaum, hvorki á ákvæðum laga nr. 106/2000 um mat á umhverfisáhrifum, sem rétt er að nefna hér, né ákvæðum laga nr. 91/1991 um meðferð einkamála. Breyting sú sem varð með fyrrnefndu lögunum á árinu $2005^{9}$ hafði ekki áhrif, eins og vikið er að í sératkvæði. Pá er ekki að sjá að orðið hafi grundvallarbreytingar á almennum reglum stjórnsýslulaga eða stjórnsýsluréttar. Í peim forsendum, sem teknar eru upp að framan, er leitað fanga í óbreyttum ákvæðum í III. kafla laga nr. 91/1991 um meðferð einkamála, sem fjallar um aðild og fyrirsvar. Í fyrri dómum um petta vandamál var engum steinum velt í ákvæðum pessara laga. Рað er með öðrum orðum reynt að finna pví stoð í ákvæðum laganna undir hvaða kringumstæðum fleiri en einum aðila verði stefnt í einkamáli vegna ógildingar á stjórnvaldsathöfn. Í pessu tilviki má geta pess að báðir varnaraðilar deilunnar eru stjórnvöld, en hins vegar verður að taka með í reikninginn að Vegagerðin er í pessari deilu aðili sem skálmar fram á einkaréttarlegu sviði sem framkvæmdaraðili.

Nauðsynleg samaðild eftir 18. gr. EML verður ofan á ef um óskipt réttindi eða óskipta skyldu er að ræða. Frávísun er par sjálfgefin ef út af bregður. Sérkennilegt er hins vegar að ráðherra hafi ekki verið talinn réttilega að deilunni kominn undir merkjum 19. gr. EML með pví að sakarefnið sé óumdeilanlega sprottið af sömu aðstöðu - jafnvel af sömu rót. Hæstiréttur kveður hins vegar upp úr með að ekki geti komið til kasta pessa lagaákvæðis par sem stefnendur málsins gætu aldrei talist eiga sjálfstæða kröfu á hendur hvorum varnaraðila um ógildingu úrskurðar umhverfisráðherra, sem peim væri í sjálfsvald sett hvort sótt yrđi i einu dómsmáli eða tveimur. Pá er umfjöllun um 1. mgr. 19. gr. laga nr. 91/1991 sérkennileg í ljósi pess að ekki verður séð að íslenska ríkið hafi byggt frávísunarkröfu sína á peirri grein. Frávísun á grundvelli pess að skilyrðum samlagsaðildar eftir 1. mgr. 19. gr. sé ekki fullnægt er háð kröfu par að

9 Lög nr. 74/2005 um breytingu á lögum nr. 106/2000 um mat á umhverfisáhrifum. 
lútandi. Ef álitamál um svo prönga túlkun á ákvæði 19. gr. væru stundarkorn lögð til hliðar mætti í sama vetfangi nefna að í sératkvæði eins dómara var einmitt nefnt að dómar væru til par sem fleira en eitt stjórnvald eða stjórnvald og einkaaðilar hefðu verið aðilar að dómsmáli um ógildingu stjórnarathafnar.

Sem fyrr segir töldu tveir peirra dómenda, sem stóðu að niðurstöðu meirihlutans, að finna pyrfti henni stoð í lögum, prátt fyrir pessi mörgu fordæmi sem til voru. Einn dómari skilaði sératkvæði par sem hann var sammála niðurstöðu meirihlutans, en með öðrum rökstuðningi. Hann tók fram að fjölmörg dæmi væru um pað í dómum Hæstaréttar að fleiri en einn aðili væri til varnar eða sóknar í einkamálum án pess að uppfyllt væru skilyrði 18. eða 19. gr. laga nr. 91/1991 eins og pau væru skýrð í niðurstöðu peirra tveggja dómenda sem lögðu grunn að niðurstöðu málsins. Á petta verður að fallast en geta pess pó, að máli verður ekki vísað frá dómi á grundvelli 1. mgr. 19. gr. nema pess sé krafist. Pannig getur fjöldi aðila til sóknar eða varnar í einkamáli einfaldlega helgast af pví að frávísunar á grundvelli 19. gr. er ekki krafist. Dómarinn bendir réttilega á í sératkvæðinu að petta helgist einnig af pví að ekki hafi verið talið rétt að dæma um mál nema peim, sem átti lögvarða hagsmuni af úrlausninni, yrði gefinn kostur á að tjá sig um pað. Аð öðru leyti rökstyður dómarinn niðurstöðu sína um staðfestingu úrskurðarins með pví að greina hagsmuni íslenska ríkisins í málinu og kemst að peirri niðurstöðu að peir séu ekki fyrir hendi, aðeins hafi ráðherra verið hlutlaus úrskurðaraðili. Að mörgu leyti má halda pví fram að pessi rökstuðningur sé eðlilegri út af fyrir sig en hinna tveggja dómendanna sem einnig vildu staðfesta úrskurð héraðsdóms. Ástæðan er sú að dómarinn heldur sig í raun nær peim fordæmum sem fyrir hendi voru og hafnar pví að pessi varnaraðili hafi haft lögvarða hagsmuni.

Í sératkvæði tveggja dómenda annarra, sem vildu hrinda úrskurði héraðsdóms, voru fyrri fordæmi Hæstaréttar um petta efni gagnrýnd og peim hafnað. Atkvæði peirra er sérlega áhugavert, ekki bara sökum pess að par er reynt að kryfja inn að beini hvernig réttarfarsreglur og reglur stjórnsýsluréttar horfa við aðild ríkisins í pessu tilviki. Atkvæði peirra geymir einnig markvissa gagnrýni á fyrri fordæmi. Peir benda á að ekki sé að finna sérstök ákvæði um pað í lögum um meðferð einkamála hvernig haga beri aðild til varnar í málum par sem leitast er við að hnekkja stjórnvaldsákvörðun. Sú óskráða meginregla hafi verið talin gilda að stefna beri pví stjórnvaldi sem í senn er aðildarhæft og bært til að taka pá ákvörðun, sem ógildingar er krafist á, nema annað leiði af lögum eða venju. Sömu undirstöðurök gildi um fyrirsvar stjórnvalda í slíkum málum, sbr. 5. mgr. 17. gr. laga nr. 91/1991. Peir benda einnig réttilega á að venja leiði til pess að ekki beri að stefna sjálfstæðum stjórnsýslunefndum á kærustigi pegar pess er freistað að hnekkja ákvörðunum peirra. Hér vísa dómendurnir í tvígang til venju. Hið fyrra sinn lýsa peir óskráðri meginreglu en gera við hana fyrirvara á grundvelli venju. Í hinu síðara telja peir venju leiða til pess að ekki beri að stefna sjálfstæðum stjórnsýslunefndum. Væntanlega er hér átt við dómvenju sem ítrekuð fordæmi renna stoðum undir. Engu að síður gera peir vissa 
atlögu að pessari dómvenju gegn niðurstöðu meirihlutans. Atkvæði peirra lýsir nefnilega gagnrýni á pá dómaframkvæmd sem hófst árið 1997. Í sératkvæði peirra segir:

Á árinu 1997 hóf Hæstiréttur að beita sambærilegri undantekningu um ráðherra frá framangreindri meginreglu pegar aðstaðan var sú að peir höfðu úrskurðað í máli á grundvelli stjórnsýslukæru. Vísaði rétturinn pannig frá kröfum á hendur ráðherra að eigin frumkvæði, sbr. dóma í dómasafni réttarins frá 1997, bls. 2856 og 2918. Pessi breyting var ekki gerð á grundvelli nýrra laga heldur með ákvörðun réttarins um að breyta áralangri og viðtekinni skýringu á 19. gr. laga nr. 91/1991 sem var að pessu leyti í samræmi við skýringu 47. gr. laga nr. 85/1936 um meðferð einkamála í héraði. Samkvæmt hinni viðteknu skýringu á ákvæðum pessum var lagt til grundvallar að samlagsaðild varnarmegin yrði hagað með peim hætti að stefna mætti pví stjórnvaldi er hina umdeildu ákvörðun hafði tekið svo og rétthafa ákvörðunarinnar par sem gerð var krafa um ógildingu hennar, enda kröfur á hendur aðilunum samrættar par sem pær voru báðar sprottnar af sömu stjórnvaldsákvörðuninni sem í senn var að lögum bindandi fyrir stjórnvaldið og pann, sem ákvörðuninni var beint til eftir að hún hafði verið birt. Af peim fjölmörgu málum par sem aðild hefur verið svo háttað má sem dæmi nefna dóma sem birtir eru í dómasafni réttarins frá árinu 1981, bls. 1183, frá árinu 1983, bls. 1655 og frá árinu 1993, bls. 2364.

Í pessu sératkvæði er einnig bent á að pótt hin breytta skýring, sem peir rekja aftur til ársins 1997, hafi vikið frá meginreglunni um varnaraðild stjórnvalda, pá hafi henni ekki verið beitt í öllum málum sem dæmd hafi verið frá árinu 1997 enda sé staða ráðherra önnur en sjálfstæðra stjórnsýslunefnda að pví er varðar almennar stjórnunarheimildir, svo og ráðherraábyrgð. Petta er nánar rökstutt með pví að ráðherra geti haft hagsmuni af máli, auk pess sem hann hafi forræði á sakarefni er lýtur að stjórnvaldsákvörðunum sem hann hafi sjálfur tekið innan peirra marka sem leiðir af reglum réttarfars og stjórnsýsluréttar. Í pessu skyni eru nefndir fjórir dómar Hæstaréttar. ${ }^{10}$

Peir halda áfram og gagnrýna pessa dómaframkvæmd sem og pá stefnubreytingu sem komst á árið 1997. Segja peir að par sem forsendur pessara dóma hafi ekki að geyma skýr viðmið um pað hvenær heimilt er að stefna ráðherrum vegna úrskurða peirra á æðra stjórnsýslustigi ríki réttaróvissa um pað í ljósi peirrar stefnubreytingar sem varð árið 1997. Pessa afstöðu má jafnvel skilja sem svo að dómendurnir tveir vilji ekki dæma beinlínis gegn fyrri fordæmum sem fólu í sér stefnubreytingu, heldur sé óhjákvæmilegt að fara nánar í saumana á pví hvaða réttarregla skuli gilda, enda ríki um pað réttaróvissa. Við svo búið rökstyðja peir niðurstöðu sína með pví að leita skýringa á pví hvort réttarfarslög og reglur stjórnsýsluréttar geti með réttu leitt til pess að vísa beri frá héraðsdómi kröfum á hendur íslenska ríkinu. Með pessu móti virðast dómendurnir tveir takast á við pað hvort meðferð réttarheimilda í fyrri fordæmum hafi verið rétt. Bent er meðal annars á að skilyrðið um lögvarða hagsmuni hafi almennt verið notað um greiningu á hagsmunum stefnanda máls að einkarétti en ekki hagsmuni hins opinbera. Рað að stjórnvald hafi að lögum

10 Nefndir eru í sératkvæðinu hrd. 2002, bls. 2241, hrd. 2003, bls. 673, hrd. 2004, bls. 171 og hrd. 2004, bls. 2760 . 
verið fengið vald til að taka ákvörðun leiði til pess að pað hafi lögvarða hagsmuni af varnaraðild um ákvarðanir sínar og purfi að standa skil gerða sinna, sbr. 60. og 70. gr. stjórnarskrárinnar. Í reynd hafi dómaframkvæmd gengið út frá pví að varnaraðild fleiri en eins við pessar aðstæður hafi verið talin heimil væru skilyrði 1. mgr. 19. gr. laga nr. 91/1991 uppfyllt. Pá telja peir að í niðurstöðu dómendanna tveggja, sem studdu niðurstöðu meirihlutans, hafi nefnd 19. gr. raunar verið túlkuð strangar en áđur hafi verið gert. Loks er farið yfir á hvern hátt málatilbúnaður peirra, sem vildu hrinda ákvörðun ráðherra, kallar óhjákvæmilega á aðild hans vegna íslenska ríkisins út frá ýmsum reglum stjórnsýsluréttar, einkum um málsmeðferð, en með peirri aðild hljóti möguleikar til að upplýsa sakarefnið á vandaðan hátt að aukast til muna.

Athygli vekur að í atkvæðum dómendanna fimm er hvergi getið dóms sem fallið hafði liðlega premur mánuðum fyrr eða pann 14. mars 2008 í málinu nr. 114/2008. Par var höfð upp svofelld kröfugerð fyrir héraði:

Stefnendur gera pær dómkröfur að ógiltur verði úrskurður umhverfisráðherra frá 11. maí 2007, mál ráðuneytisins nr. 06120018, vegna kæru Vegagerðarinnar, par sem hluti ákvörðunar Skipulagsstofnunar frá 5. desember 2006, um matsáætlun vegna mats á umhverfisáhrifum lagningar Hringvegar um Hornafjarðarfljót í sveitarfélaginu Hornafirði er felldur úr gildi.

Deilt var um hvort stefnendur ættu lögvarða hagsmuni af úrlausn um pessar kröfur. Hæstiréttur taldi svo vera en vék einnig að aðild Vegagerðarinnar og íslenska ríkisins með svofelldum orðum:

Fallist er á með sóknaðilum að réttarfarsástæður standi til pess að gefa ráðherra kost á að láta mál petta til sín taka. Pá verður krafa sóknaraðila ekki tekin til meðferðar án pess að framkvæmdaraðili eigi aðild að málinu, sbr. til hliðsjónar dóm Hæstaréttar í máli nr. 231/2002 í dómasafni réttarins pað ár, bls. 2241.

Tveir af premur dómurum voru hinir sömu og skiluðu sératkvæði í dóminum frá 18. júní, að pví er best verður séð, í samræmi við niðurstöðuna premur mánuðum áður.

Peirri skoðun hefur verið lýst að dómar af pessum meiði kalli á lagasetningu. ${ }^{11}$ Dómar Hæstaréttar kunna að kalla á lagasetningu vegna pess að pað reynist óhjákvæmilegt að gera breytingar á lögum í kjölfar peirra. Lög stóðust ekki stjórnarskrá eða löggjafinn taldi einfaldlega að niðurstaða kallaði á breytingar. Löggjafinn tekur pá nýja afstöðu til pess hvaða réttarstaða eigi að gilda á tilteknu sviði. Dómurinn frá 18. júní 2008 kallar hins vegar á lagasetningu vegna peirrar óvissu sem orðin er, burtséð frá pví hvaða leið menn telja hina réttu um aðild ríkisins. Rétturinn príklofnar. Tveir dómenda reyna að finna fyrri niðurstöðum stoð í settum lögum, einn dómari rökstyður frekar fyrri fordæmi að pví er virðist, en tveir aðrir hafna fyrri fordæmum að pví er best verður séð. Fyrirmyndina að lagabreytingu um petta efni mætti e.t.v.

11 Sjá áður tilvitnaða grein Skúla Magnússonar. 
sækja í norskan rétt par sem svofellt ákvæði er að finna í grein 1-5 einkamálalaganna: ${ }^{12}$

Søksmål om gyldigheten av forvaltningsvedtak reises mot den myndighet som har truffet avgjørelsen i siste instans. Er dette et statlig organ, skal retten gi varsel om søksmålet til en kommune eller fylkeskommune som har truffet avgjørelse i saken i tidligere instans.

Рað má með öðrum orðum halda pví fram með rökum að dómurinn og dómaframkvæmdin sem tekist var á um kalli á lagasetningu. Verður pá ekki lengur staldrað við vandamálið um aðild ríkisins í dómsmálum vegna stjórnvaldsathafna. En dómur pessi er með hurðum og gluggum. Fimm dómarar dæmdu en ekki prír sem fyrr sagði. Dómendur voru ekki einhuga í afstöðu sinni til pess hvernig bæri að skýra réttarfarsákvæði og síðast en ekki síst fordæmi réttarins sjálfs. Hin breytta dómaframkvæmd sem fjallað var um var í reynd dómvenja og stefnubreyting sem dómstóllinn sjálfur átti upptökin að. En pað má deila um fordæmisgildi pessa dóms frá 18. júní 2008. Deila má um pá kenningu að fordæmisgildi dóms sé minna ef sératkvæði er greitt. Pessi dómur getur pó aflað peirri skoðun aukið fylgi.

Hér virðist vera fyrir hendi skóladæmi um pað pegar upp kemur sú staða að Hæstiréttur endurskoðar fordæmi sín. Allir dómendurnir virðast nálgast úrlausnaratriði málsins á pann hátt að kanna purfi hvort meðferð peirra réttarheimilda sem réði fyrri niðurstöðum hafi staðist. Í riti Jóns Steinars Gunnlaugssonar um fordæmi og valdmörk dómstóla er tæpt á pessu atriði. Í umfjöllun sinni um hvort fordæmi séu bindandi orðar hann pað svo að leggja beri fordæmi til grundvallar dómi í sambærilegu yngra máli nema dómstóllinn komist að peirri niðurstöðu að sú meðferð réttarheimilda, sem réði fyrri niðurstöðunni, hafi verið röng eða réttarheimildir hafi breyst eftir að hann var kveðinn upp; fordæmi sé jafn bindandi og sú réttarheimild sem lá pví til grundvallar. ${ }^{13}$

\section{Hvernig lítur Hæstiréttur almennt á gildi fordæma?}

Menn eru almennt sammála um að fordæmi er mikilvæg réttarheimild og í pví riti um almenna lögfræði, sem lengst af var kennd og byggði á rannsóknum og fyrirlestrum dr. Ármanns Snævars, er ekki um að villast. ${ }^{14}$ Í sama riti er hugtakið skýrt svo að dómsúrlausn hafi gengið um tiltekið réttaratriði og að hún sé notuð sem fyrirmynd í síðara dómsmáli. ${ }^{15}$ Samt er bent á að Hæstiréttur er ekki talinn bundinn af fyrri úrlausnum sínum og engri réttarreglu sé fyrir að fara sem leggi skyldu á héraðsdómara að fylgja fordæmi Hæstaréttar. ${ }^{16}$ Athygli vekur að í skilgreiningunni að framan er notað orðið „,réttaratriði.“ Eflaust er áherslan par á lagaatriði málsins og rýna verður pá í hvað í dómsúrlausninni skuli telja fordæmi og par af leiðandi réttar-

12 Lov om mekling og rettergang i sivile sager (tvisteloven) frá 2005.

13 Jón Steinar Gunnlaugsson, Um fordæmi og valdmörk dómstóla, bls. 83.

14 Ármann Snævarr, Almenn lögfræði (Reykjavík: Orator, 1989), bls. 158.

15 Ármann Snævarr, Almenn lögfræði, bls. 213.

16 Ármann Snævarr, Almenn lögfræði, bls. 216. 
heimild. Hefur einmitt verið bent á hversu mikilvægt er að gera pennan greinarmun, p.e. á atvikum málsins og peim réttarheimildum sem beitt var á pau. Aðeins sé pá afstaða dómsins til efnis réttarheimildarinnar sem hafi fordæmisgildi. ${ }^{17}$ Á petta verður fallist hér.

Tína má til margvísleg rök sem mæla með pví að fordæmum sé fylgt. Nokkur atriði hafa verið nefnd. Í fyrsta lagi pað að samræmi skuli vera í dómsúrlausnum, jafnræði sé með fólki. Í öðru lagi að fordæmin greiði fyrir úrlausn réttarágreinings og í priðja lagi að fordæmin létti heilabrotum og ábyrgð, eins og pað var orðað. Pá er bent á hið sígilda prætuefni hver eru mörk dómsvalds og löggjafarvalds. Dómstólar kunna að eiga auðveldar með að fella réttarpróun að breyttum pjóðfélagsaðstæðum en síðan horfist peir í augu við tiltekin mörk sem peir treysti sér ekki til að fara yfir og ætla löggjafanum að ráða fram úr. Sjónarmið hafa einnig verið reifuð gegn pessari trú á gildi fordæma. Dómstólar kunni að torvelda réttarpróun með pví að binda sig um of við fordæmi og einnig er bent á að óvissa kann að vera um fordæmið, hvernig á að skýra pað. ${ }^{18}$

Sjónarmið til stuðnings pví að fordæmi séu bindandi hefur einnig verið lýst pannig að með pví haldist ákveðin festa í réttarframkvæmd sem stuðlar að samræmi. Af pessu leiðir einnig að dómsmál eru færri. Pá er einnig bent á að með pví að víkja frá fordæmi er réttarreglum á vissan hátt beitt afturvirkt. ${ }^{19}$ Allt eru petta ápekk sjónarmið og lýst var fyrr.

Vísast kemur oftar í hlut dómstóla að ráđa í óvissu laga en löggjafans að ráđa í óvissu dómstóla. Hugmyndin um óbrigðulan Hæstarétt er sterk og væntingar til dómstóla eru miklar pegar á reynir. Geri dómarar atlögu að fordæmum og gildi peirra almennt er aukið við réttaróvissu og vafamál kunna að vakna um uppruna ríkisvalds og kenninguna um prískiptingu pess. Dómstólar hafa verið taldir íhaldsamar stofnanir í eðli sínu og margs konar skoðanir eru á pví hvort peir eiga að móta réttarreglur í meira mæli eða láta pað löggjafanum eftir.

Leidd hafa verið rök að pví að vægi fordæma hafi aukist og teljist mikilvægari réttarheimild en áður. ${ }^{20}$ Löggjafarhlutverk dómstólanna hefur einnig vaxið til muna pótt umdeilt sé og til eru dómar par sem reglur hafa verið mótaðar af nokkurri nákvæmni - jafnvel tölulega. Má par t.d. vísa til dóma Hæstaréttar par sem pví er slegið föstu að ef uppsaga dóms tefst um meira en átta vikur sé óhjákvæmilegt að vísa málinu heim par sem munnlegur málflutningur fari fram að nýju. Sé pá komið út fyrir pann ramma sem 115. gr. laga nr. 91/1991 kveður á um, um hvernig með skuli fara ef

17 Jón Steinar Gunnlaugsson, „Fordæmisgildi hæstaréttardóma,“ Tímarit lögfræðinga 42 (1992), bls. 173-174. Sjá einnig umfjöllun í riti sama höfundar frá 2003.

18 Sjá grein Pórs Vilhjálmssonar par sem hann reifar pessi sjónarmið í grein sinni „Fordæmi,“ Tímarit lögfræðinga 42 (1992), bls. 169-171.

19 Sigurður Líndal, Um lög og lögfræði, bls. 288-290.

20 Sigurður Líndal, Inngangur að lögfræði II. Réttarheimildir: fordæmi, bls. 30. 
dómsuppsaga tefst fram yfir fjórar vikur. ${ }^{21}$ Eftir pessari reglu sem Hæstiréttur mótaði og kalla má átta vikna regluna hefur verið farið æ síðan.

Peir sem ritað hafa um fordæmi hafa bent á að fyrir kemur að dómstólar lýsi reglu með mjög almennum hætti. ${ }^{22}$ Regla verður pannig til sem hluti af tilteknu réttarsviði, hvort sem lög gilda almennt um efnið eða ekki, og vísað er til fordæmisins. Dæmi um petta er hrd. 2004, bls. 731 (323/2003), par sem sagði:

Eins og greinir í héraðsdómi hefur áfrýjandi borið fyrir sig að brotinn hafi verið á honum andmælaréttur samkvæmt 13. gr. stjórnsýslulaga við málsmeðferð stefnda. Áfrýjandi hefur í engu borið brigður á að pessa réttar hans hafi verið gætt við meðferð málsins fyrir áfrýjunarnefnd samkeppnismála. Samkvæmt pessu og með vísan til dóms Hæstaréttar 30. október 2003 í máli nr. 37/2003 geta atriði, sem varða andmælarétt áfrýjanda á lægra stjórnsýslustigi, ekki varðað ógildingu úrskurðar áfrýjunarnefndarinnar.

Í pessu tilviki er almenn regla leidd af fordæmi og hún orðuð beinlínis eins og lagabókstafur. Parna er eins og byggt sé traustar undir fordæmið og reglan nær festu. Annað dæmi um pað hvernig Hæstiréttur setur fram tiltekin viðmið um skýringu á lögum er hrd. 17. janúar 2006 í málinu nr. 538/2005, par sem sagði: „Í dómafordæmum Hæstaréttar kemur fram að ófrávíkjanlegt skilyrði pess að unnt sé að nýta sér réttarfarshagræði 1. mgr. 19. gr. laga nr. 91/1991 er að hver kröfuhafi geri sjálfstæða aðgreinda kröfu og varðar pað frávísun máls af sjálfsdáðum sé petta ekki gert, sbr. dóma réttarins 6. september 2005 í máli nr. 294/2005 og 21. október sama ár í máli nr. 439/2005." Раð fer vel á að grípa pessar forsendur á lofti, pví pað var einmitt pessi túlkun á nefndri 19. gr. sem dómendur voru ekki sammála um pegar vandamálið snerist um aðild íslenska ríkisins í dómi réttarins frá 18. júní 2008.

раð hlýtur að koma upp öðru hvoru að lögfræðingar telja ekki fullt samræmi í dómaframkvæmd og líta pá svo á að fyrir hendi sé réttaróvissa. Dæmi um pað eru úrlausnir dómstóla um pað hvaða kröfur réttarfarslög gera til pess að unnt sé að krefjast einungis viðurkenningar á bótaskyldu. Petta er klassískt vandamál. Er pá til skoðunar hversu ríkar kröfur verði að gera til reifunar máls og ekki síður hvaða sönnunarfærsla um ætlað tjón sé óhjákvæmileg, pótt bótakrefjandi telji ekki kleift að setja fram endanlega fjárkröfu og fullnægjandi gögn henni til stuðnings. Eru pá til skoðunar ákvæði 2. mgr. 25. gr. og 1. mgr. 80. gr. laga nr. 91/1991. Eru dæmi pess að viðurkenningarmálum af pessum toga hafi verið vísað frá en sum hafa talist tæk til efnismeðferðar. Ekki skal fullyrt að dómaframkvæmdin sé misvísandi par sem tilvikin eru breytileg og einnig hagsmunir bótakrefjanda um að haga máli sínu á pann veg að krefjast einungis viðurkenningardóms. Í dómi Hæstaréttar frá 6. febrúar 2009 í málinu nr. 2/2009 er vísað til dómaframkvæmdar um petta og rétturinn dregur saman tiltekin sjónarmið um pá reglu sem mótuð hafi verið með pessum orðum:

Á grundvelli heimildar í 2. mgr. 25. gr. laga nr. 91/1991 leita sóknaraðilar með pessum kröfum dóms um viðurkenningu á skaðabótaskyldu varnaraðila án pess að staðreynt hafi

21 Sjá hrd. 1995, bls. 304.

22 Sjá t.d. Sigurður Líndal, Um lög og lögfræði, bls. 223 o.áfr. 
verið hvert tjón peirra kunni að geta talist. Samkvæmt dómaframkvæmd Hæstaréttar er mál um kröfu sem pessa tækt til efnisdóms ef afmarkað er nægilega hver pau atvik séu, sem geti leitt af sér kröfu um skaðabætur peim til handa sem málið höfðar, og í hverju tjón hans geti verið fólgið, sbr. meðal annars dóm réttarins 17. nóvember 2005 í máli nr. 182/2005, sem birtur er í dómasafni pess árs á bls. 4506.

Hér eru rakin nýleg dæmi pess að fordæmi eru fest í sessi, Hæstiréttur dregur jafnvel saman hvað felst í dómaframkvæmd sem hugsanlega er vandskýrð á köflum. Par kemur eflaust til sú viðleitni að auka samræmi í réttarframkvæmd og pað er ein helsta röksemdin fyrir pví að fylgja fordæmum.

Dæmi eru einnig um að Hæstiréttur hafi horfið frá fyrra fordæmi á einlægan og afgerandi hátt. Í dómi Hæstaréttar frá árinu 2001 sagði: „Fyrri niðurstöður dómstóla um að áhættutaka, eins og hér er um fjallað, leiði til niðurfellingar bóta, hafa sem fyrr segir ekki byggst á lögfestri reglu heldur mótast af almennum viðhorfum og kenningum í skaðabótarétti og leitt til dómvenju, sem hefur verið talin bindandi. Pegar litið er til pess, sem að framan er rakið, pykja ekki efni til pess lengur að halda henni við.“ ${ }^{23}$ Pá má líka nefna dóma sem fallið hafa nýlega um fyrningarákvæði 99. gr. umferðarlaga nr. 50/1987 par sem deila má um hvort greinin sé skýrð á sama hátt í einstökum dómum. ${ }^{24}$

Prátt fyrir petta er raunin sú að Hæstiréttur víkur alla jafna ekki frá fordæmum sínum pegar pau eiga við og að óbreyttum lögum. Hæstiréttur vísar sjálfur oft til dóma sinna pegar lýst er peirri réttarreglu sem viðkomandi mál veltur á. Tæplega er um pað deilt að lögfræðingar meta fordæmi Hæstaréttar sem veigamikla réttarheimild, bæði í rannsóknum sínum, álitsgerðum, ráðgjöf, margs konar ákvörðunum og málflutningi. Pessa trú á fordæmi sem réttarheimild endurspeglar Hæstiréttur sjálfur á ýmsan hátt. Um petta má nefna fjölmörg dæmi, en tiltaka mætti nokkra dóma til að sýna hvaða orðalag kemur við sögu og hver efnistökin eru pegar rétturinn fjallar um fordæmi sín. Minnt skal á að hér er ekki um neina tæmandi útlistun að ræða heldur valdir dómar par sem orðalagið er dæmigert. Og einnig verður að hafa í huga hin hefðbundu sjónarmið um mat á fordæmisgildi, aldur dómsins, hvort fordæmin eru mörg á sömu lund, orðalag í dómi, fjölda dómara, á hvaða sviði sakarefnið er, hvort greitt var sératkvæði o.s.frv. ${ }^{25}$

Taka má dæmi par sem Hæstiréttur kveður fast að orði. Í dómi réttarins frá 2001 á bls. 4341 í dómasafni (197/2001) var til úrlausnar hvernig færi með rétt sjómanns til launa í uppsagnarfresti. Í dómi Hæstaréttar sagði:

Við flutning málsins fyrir Hæstarétti hefur áfrýjandi einkum vísað til dóms réttarins 29. mars 2001 í máli nr. 326/2000 til stuðnings pví að hann eigi rétt á aflahlut í uppsagnarfresti og purfi ekki að sætta sig við að greiðsla kauptryggingar feli í sér fullnaðaruppgjör

23 Sjá hrd. 21. október 2001 í málinu nr. 129/2001.

24 Sjá um pað nýlegan dóm Hæstaréttar frá 2. apríl 2009 í málinu nr. 418/2008, en par er vísað til priggja annarra dóma. Peim til viðbótar má nefna hrd. 6. mars 2008 í málinu nr. 353/2007og hrd. 13. nóvember 2008 í málinu nr. 77/2008.

25 Sigurður Líndal, Inngangur að lögfræði II. Réttarheimildir: fordæmi, bls. 58-64. 
af hálfu stefnda. Ekkert er fram komið um að skipið hefði að óbreyttu ekki verið gert út á pví tímabili, sem krafa áfrýjanda tekur til, og óumdeilt er að hann var ráðinn par upp á aflahlut. Skipinu var lagt og pað síðan selt, en af pví leiddi að áfrýjandi fékk ekki lengur greiddan hlut af afla skipsins, enda ekki lengur um hann að ræða. Er fallist á með áfrýjanda að áðurnefndur dómur Hæstaréttar feli í sér fordæmi, sem hér beri að líta til, og leiðir til peirrar niðurstöðu að áfrýjandi telst eiga rétt á aflahlut í uppsagnarfresti sínum.

Í hrd. 2002, bls. 4277 (319/2002) var einnig deilt um hver laun skyldi greiða sjómanni í uppsagnarfresti og varð að túlka ákvæði kjarasamnings par að lútandi. Hæstiréttur sagði í forsendum sínum:

Framangreind ákvæði kjarasamningsins taka eingöngu til pess, pegar dráttur verður á pví, að skipið fari í næstu veiðiferð en ekki til pess að útgerð skips til fiskveiða sé hætt. Í kjarasamningnum eru engin ákvæði um hvernig með launagreiðslur skuli fara, pegar pannig stendur á. Er fallist á með héraðsdómi, að dómur Hæstaréttar í máli nr. 326/2000 hafi fordæmisgildi í pessu máli.

Hér var vísað í sama fordæmið. Orðalagið má í báðum tilvikum túlka svo að við úrlausn málsins hafi verið óhjákvæmilegt að reisa niðurstöðu málsins á pví fordæmi réttarins sem vísað var til. ${ }^{26}$

Um skýringu á tilteknu lagaskilyrði par sem vísað er til fordæmis má nefna hrd. 9. júní 2005 í málinu nr. 72/2005, par sem sagði: „Að virtum dómi Hæstaréttar 20. nóvember 2003 í máli nr. 333/2003 verður að telja pað skilyrði fyrir upptöku á jafnvirði ávinnings af broti að sýnt sé fram á að fjármunir til upptöku séu fyrir hendi. Verður pví ekki hjá pví komist að sýkna ákærðu af kröfum ákæruvalds um upptöku. " Nefna má að petta er einn fárra dóma í seinni tíð par sem Hæstiréttur notar orðið fordæmi sem lykilorð í dómasafni.

Pegar fordæmi eru ítrekuð kemur fyrir að Hæstiréttur nefnir pað sérstaklega til áréttingar. Í dómi frá 10. desember 2007 í málinu nr. 626/2007 kvað við pennan tón: „Samkvæmt áðurnefndri beiðni um fjárnám 3. apríl 2006 var höfuðstóll kröfunnar, sem leitað var fullnustu á, 17.923 danskar krónur. Skilyrði um áfrýjunarfjárhæð í 1. mgr. og 2. mgr. 152. gr. laga nr. 91/1991 verður beitt um kæru sem pessa, sbr. 4. mgr. 150. gr. laganna og 3. mgr. 95. gr. laga nr. 90/1989, svo sem ítrekað hefur verið í dómaframkvæmd Hæstaréttar eftir að dómur gekk, sem birtur er í dómasafni réttarins 1994, bls. 1101. Krafan, sem mál petta varðar, nær ekki áfrýjunarfjárhæð samkvæmt fyrstnefnda lagaákvæðinu."

Í raun má finna alls kyns orðalag í dómum par sem fordæmum er beitt. Er stundum sagt að líta beri til fordæmis eins og dæmi var tekið um, dómur hafi fordæmisgildi, eða að vísað er í tiltekinn dóm "til hliðsjónar“, sbr. t.d. hrd. 20. desember 2007 í málinu 185/2007. Einnig sést orðalag par sem sagt er að tiltekið ákvæði laga hafi verið skýrt á tiltekinn veg með hæstaréttardómi, einum eða fleirum (sjá t.d. hrd. 4. júní 2003 í málinu nr. 215/2003). Jafnvel lætur Hæstiréttur við pað sitja að lýst er í stuttu máli réttarreglunni sem beitt er og síðan er vísað í dóminn með pví að skamm- 
stafa orðið samanber á undan. Dæmin eru mörg en til pess eins að hafa ekki sleppt pví skal hér vísað til hrd. 9. febrúar 2009 í málinu nr. 47/2009. Pegar svo háttar til virkar orðalagið eins og að ekki sé um að villast að viðkomandi fordæmi eigi við. Og stundum er af nógu að taka og hnýtt er við orðið sbr. orðin til dæmis (sjá hrd. 11. október 2007 í málinu nr. 61/2007).

Stefnumarkandi dómar hafa einnig verið nefndir oft í málum sem risið hafa á tilteknu lagasviði, eins og oft hefur komið fram í málum er varða mörk pjóðlendu og eignarlanda. Í mörgum peirra hefur t.d. dómur Hæstaréttar frá 21. október 2004 í málinu nr. 48/2004 (hrd. 2004, bls. 3796) ítrekað verið nefndur og lagaatriði sem par reyndi á reifuð.

Pess eru dæmi að Hæstiréttur taki afstöðu til pess hvaða fordæmi er rétt að leggja til grundvallar af fleirum, sbr. hrd. 2003, bls. 4202 (217/2003):

Mál hafa áđur verið borin undir dómstóla, par sem ágreiningur reis milli kaupanda og seljanda fiskiskips um pað hvorum veiðireynsla skipsins tilheyrði pegar takmarkanir voru settar á veiði á fisktegundum, sem áður mátti veiða án takmarkana, og ekki var kveðið á um pað í samningi aðila. Peir dómar Hæstaréttar, sem einkum koma til álita sem fordæmi í pessu sambandi, eru dómur 1996, bls. 126 í dómasafni réttarins pað ár, dómur 1998, bls. 799 og dómur 21. júní 2001 í máli nr. 40/2001. Í fyrstnefnda dóminum var skorið úr ágreiningi um pað hvorum samningsaðila veiðireynsla í skarkolaveiðum tilheyrði, en til viðmiðunar um rétt til aflamarks og aflahlutdeildar í pessum veiðum var tekið tímabil meðan seljandi átti skipið. Varð niðurstaða málsins sú að seljandi ætti pennan rétt og hafi kaupanda borið að efna kaupsamninginn með pví að framselja viðsemjanda sínum aflahlutdeild í skarkola, pegar kaupandinn fékk henni úthlutað eftir eigendaskiptin á skipinu. Aðstaðan í pví máli, sem hér er til úrlausnar, er í meginatriðum sambærileg peirri, sem var í áđurnefndu máli. Verður ekki komist hjá að fallast á með gagnáfrýjanda að líta beri til pessa dóms sem fordæmis við úrlausn um ágreining málsaðila nú. Verður samkvæmt pví fallist á að gagnáfrýjandi hafi átt rétt á að fá í sinn hlut aflamark og aflahlutdeild, sem ágreiningur málsaðila snýst um. Aðaláfrýjandi kom í veg fyrir að gagnáfrýjandi gæti nýtt sér umrædd réttindi og er pví skylt að svara gagnáfrýjanda skaðabótum vegna tjóns, sem hann varð fyrir af peim sökum. Hinir dómarnir tveir, sem að framan var getið, breyta ekki pessari niðurstöðu, enda atvik par ólík um mikilvæg atriði. Í málinu frá 1998 var deilt um veiðireynslu á steinbít, en gagngert var tekið fram í reglugerð um takmarkanir á heildarafla á peirri fisktegund að hafi veiðileyfi verið flutt milli skipa fylgdi aflareynslan veiðileyfinu. Ekki var hins vegar kveðið á um petta í reglugerð nr. 631/2001 varðandi takmörkun á heildarafla keilu, löngu og skötusels. Í málinu frá 2001 laut ágreiningurinn að veiðireynslu á úthafskarfa og porski utan íslensku efnahagslögsögunnar. Var tekið fram í dómi Hæstaréttar að um væri að ræða veiðar utan íslensku lögsögunnar, pær hafi verið öllum frjálsar og ekki lotið heildarstjórnun stjórnvalda fyrr en um premur árum eftir sölu umrædds skips og að seljandinn hafi átt skip, sem engan veiðirétt átti í íslensku lögsögunni. Gætu eldri dómar pví ekki haft fordæmisgildi í pví máli.

Um álagningu skatta og gjalda hefur Hæstiréttur vísað í fyrri fordæmi og metið hvort álagning gjalds, pótt hún væri með öðrum hundraðshluta og á öðrum tíma, stæðist eftir fyrri fordæmum. Bregða varð pá mælistiku peirra á hið nýja sakarefni, sbr. hrd. 2000, bls. 2008 (501/1999): 
Með dómi Hæstaréttar 19. desember 1996 í máli protabús S. Óskarssonar \& Co. hf. gegn íslenska ríkinu, H.1996.4260, var komist að peirri niðurstöðu, að álagning 190\% og 120\% jöfnunargjalds, sem ákveðið var í reglugerð nr. 223/1987, eins og henni var breytt með reglugerðum nr. 109/1988 og nr. 335/1989, hefði verið ólögmæt.

Í máli pessu reynir ennfremur á álagningu 90\% jöfnunargjalds á sömu vörur samkvæmt reglugerð nr. 468/1993, sem byggð var á fyrrgreindu ákvæði laga nr. 99/1993. Um hana var fjallað í tveimur dómum Hæstaréttar 16. mars 2000, annars vegar í máli nr. 329/1999, Ástríður Hauksdóttir o.fl. gegn íslenska ríkinu og gagnsök, og hins vegar í máli nr. 359/1999, Dreifing ehf. gegn íslenska ríkinu. Varð niðurstaðan par einnig á pann veg, að sú álagning hefði verið ólögmæt.

Með vísan til pessara dóma verður litið svo á, að sú álagning jöfnunargjalds á innflutning áfrýjanda og Garra ehf., sem endurgreiðslukröfur áfrýjanda lúta nú að, hafi verið ólögmæt.

Hér er augljóst að leitast er við að tryggja samræmi í dómum. Pegar sakarefni og raunar lögskýring er háð mati sýnast dómstólar einnig fara pessa leið, eins og sést af hrd. 2000, bls. 3986 og 3995 (159 og 160/2000):

Á peim tíma, er áfrýjandi greiddi hið umdeilda lyfjaeftirlitsgjald, voru lög nr. 14/1905 um
fyrning skulda og annarra kröfuréttinda talin ná til endurkrafna ofgreiddra gjalda í opin-
bera sjóði, en nú gilda um petta efni lög nr. 29/1995 um endurgreiðslu oftekinna skatta og
gjalda, sem öðluðust gildi 1. janúar 1996. Fyrningarfrestur samkvæmt pessum síðar-
greindu lögum er fjögur ár, og er í greinargerð með lögunum miðað við, að hann sé
óbreyttur frá pví, sem áður gilti. Rétt er að miða fyrningartíma hér við fjögur ár sam-
kvæmt 5. tl. 3. gr. fyrningarlaga, sbr. og dóm Hæstaréttar 10. desember 1998, H.1998.4180.

Eins og nefnt var eru dómstólar ekki líklegir til að víkja frá fordæmum. Peir virðast alla jafna fremur telja sig bundna af peim prátt fyrir að fram komi ný lagarök eða a.m.k. einhver blæbrigðamunur á pví hvaða réttarheimildir eru bornar fram til stuðnings í nýju máli um hliðstæð atvik. Í einum peirra dóma sem vörðuðu ákvæði skaðabótalaga nr. 50/1993 gagnvart stjórnarskrá (hrd. 2004, bls. 323 (283/2003)) voru svofelldar forsendur:

Með dómi Hæstaréttar í máli nr. 127/2002 var skorið úr ágreiningi um uppgjör bóta fyrir missi framfæranda vegna banaslyss, sem varð eftir gildistöku laga nr. 37/1999. Verður ekki hjá pví komist að fallast á með áfrýjanda að dómurinn sé skýrt fordæmi um að pær greiðslur úr almannatryggingum og 40\% örorkulífeyris, sem áður hefur verið getið um, skuli koma til frádráttar við uppgjör bóta fyrir missi framfæranda. Verður samkvæmt pví fallist á sýknukröfu áfrýjanda og fær tilvísun stefndu til 72. gr. og 65. gr. stjórnarskrárinnar ekki breytt peirri niðurstöðu. Er pá litið til pess að með gildistöku skaðabótalaga var verulega breytt reglum um bætur fyrir missi framfæranda, svo sem ítarlega var skýrt í athugasemdum, sem fylgdu frumvarpi til laganna. Samkvæmt pví voru ákvæði um dánarbætur í aðalatriðum staðlaðar og um leið einfaldaðar að mun í samanburði við eldri reglur. Páttur í stöðlun bótanna var að pær skyldu ekki nema lægri fjárhæð en 3.000.000 krónum og jafnframt litið framhjá pví hvort tjónpoli í einstökum tilvikum væri sjálfur fær um að afla vinnutekna, hvort hann gerði pað í raun og hve háður hann hafi annars verið framfærslu af hálfu hins látna. Hefur áđur verið hafnað í nokkrum dómum Hæstaréttar að með setningu skaðabótalaga hafi verið brotið í bága við vernd aflahæfis manna samkvæmt stjórnarskrá á peim grundvelli að lögin tryggi ekki fullar bætur, sbr. til dæmis dóm réttarins í máli nr. 311/1997 í dómasafni 1998, bls. 1976. 
Petta horfir öðru vísi við ef bornar eru fram annars konar málsástæður. Með öðrum orðum má segja að fordæmisgildi dóms sé sterkt pegar um hliðstæð atvik er að ræða og að pví marki sem byggt er á sömu málsástæðum. Petta sjónarmið hefur komið skýrt fram í dómum, sbr. hrd. 2005, bls. 5217 (315/2005):

Svo sem getið er í héraðsdómi féll í Hæstarétti 17. desember 1998 dómur í máli nr. 166/1998: Gunnar Pétursson gegn íslenska ríkinu, sem birtur er á blaðsíðu 4406 í dómasafni pað ár. Áfrýjandinn í pví máli krafðist pess að felld yrði úr gildi álagning iðnlánasjóðsgjalds og iðnaðarmálagjalds á árunum 1995 og 1996. Málatilbúnaður áfrýjandans var reistur á málsástæðum, sem að verulegu leyti eru pær sömu og málsástæður áfrýjanda pessa máls. Er fallist á með stefnda að líta verði til pess dóms sem fordæmis í pví máli, sem hér er til úrlausnar, að pví marki sem leyst var úr málsástæðum í eldra málinu sem einnig er teflt fram nú til stuðnings kröfu áfrýjanda.

Í dóminum frá 2004 sem nefndur var um ákvæði skaðabótalaga gagnvart stjórnarskrá sést að lögð var áhersla á að Hæstiréttur hefði fyrr skorið úr um hliðstætt sakarefni. Auðfundin eru dæmi um að Hæstiréttur sé líklegur til að halda fast við nýleg fordæmi sem lúta að túlkun stjórnarskrárákvæða. Petta má t.d. sjá af hrd. 2000, bls. 3239 (178/2000), en par sagði:

Í dómi Hæstaréttar 23. mars 2000 í málinu nr. 340/1999 var dæmt um kröfur sjóðfélaga stefnda, sem hóf töku örorkulífeyris á árinu 1995 eins og áfrýjandi. Krafðist hann örorkulífeyris úr hendi stefnda á grundvelli laga nr. 49/1974 með síðari breytingum. Hélt hann pví fram að fyrrnefnd reglugerð sjóðsins frá 1994 hefði ekki verið gild heimild til skerðingar örorkulífeyris pess, sem hann hefði átt rétt á samkvæmt áðurgreindum lögum. I niðurstöðu Hæstaréttar segir að heimild löggjafans til að skerða virk lífeyrisréttindi sé mun prengri en pegar um sé að ræða réttindi, sem einungis séu væntanleg, pegar skerðingin öðlast gildi. Er par og vísað til fjárhags stefnda, pegar hinar breyttu reglur voru settar, en greiðsluprot hafi verið óumflýjanlegt að öllu óbreyttu. Var talið að skerðing allra óvirkra lífeyrisréttinda sjóðfélaga, svo sem hún birtist í fyrrgreindri reglugerð, hafi verið reist á almennum grundvelli og jafnræðis milli sjóðfélaga hafi nægjanlega verið gætt. Reglur pessar hafi verið sampykktar af samtökum sjómanna og vinnuveitenda peirra. Var talið að sú skerðing lífeyrisréttinda, sem í reglunum fólst, hafi verið innan peirra marka, sem 67. gr. stjórnarskrárinnar nr. 33/1944, nú 72. gr. hennar, setur pví að unnt sé að skerða eignarréttindi manna án pess að bætur komi fyrir. Með lögum nr. 45/1999 hefðu verið settar nýjar reglur um lífeyrisrétt sjóðfélaga stefnda. Færi um lífeyrisrétt viðkomandi sjóðfélaga samkvæmt peim eftir 1. júlí 1999, en engum haldbærum rökum hefði verið skotið undir pá kröfu að réttur hans frá peim tíma skyldi ráðast af lögum nr. 49/1974. Var stefndi sýknaður af kröfum sjóðfélagans.

Kröfur áfrýjanda í pessu máli lúta að sömu efnisatriðum og um var deilt í framangreindu máli. Pegar litið er til pess fordæmis, sem felst í niðurstöðu Hæstaréttar í pví, pykir verða að staðfesta hinn áfrýjaða dóm.

Við pessa stuttu könnun á pví hvaða orð eða sjónarmið Hæstiréttur notar um gildi fordæma má hnýta við að til kasta Hæstaréttar kom eitt skiptið mál par sem á meðal annars var deilt um hvernig ætti að skýra einn tiltekinn dóm. Lögum hafði verið breytt og lágu ljós fyrir, ákvæðum stjórnarskrár hafði verið beitt. Eftir stóð að fá dóm Hæstaréttar um pað hvort lögin í pessu tilviki væru enn í uppnámi miðað við fyrri 
dóm. Hér er vitaskuld átt við hrd. 2003, bls. 3411 (549/2002) sem kallað hefur verið öryrkjamálið hið síðara. Segja má að sakarefni pess máls hafi að stórum hluta snúist um að skýra dóm.

Réttarheimildin fordæmi er tíðum rannsökuð ítarlega. Eins og fyrr segir er sjónum pá beint að pví hvaða gildi fordæmið hefur t.d. vegna aldurs pess, hvernig mál eru lögð fyrir réttinn, hve margir dæma og hvort ágreiningur hafi orðið með dómendum. ${ }^{27}$ Pessi atriði hafa vitaskuld verið brotin til mergjar á skipulagðan hátt í nýlegum ritum og fjallað um hvernig Hæstiréttur metur fordæmi. ${ }^{28}$ Tilgangurinn með samantektinni að framan var fremur sá að taka dæmi um hvort ráða mætti af orðalagi í forsendum dóma að Hæstiréttur telji fordæmi í reynd bindandi réttarheimild og skoðaðir eru nokkrir nýlegir dómar. Niðurstaðan af pessari könnun með dæmum kemur ekki á óvart. Hæstiréttur virðist líta á fordæmi sem mjög pýðingarmikla heimild og að oftast nær sé óhjákvæmilegt að leggja hana til grundvallar, ef atvik eru hliðstæð, málið lagt fyrir með sama hætti og heimildir æðri fordæminu hafi ekki tekið breytingum. Petta kemur vitaskuld einnig fram pegar sérstaklega er tekið fram að tiltekið fordæmi eigi ekki við, eins og dæmi eru um. Hvort heldur leit að dómum er handahófskennd eða kerfisbundin kemur í ljós sterk viðleitni æðsta dómstólsins að fylgja fordæmum. Mest gildi hafa pannig nýleg fordæmi og ólíklegt er að dómstólar hörfi frá peim. ${ }^{29}$ Pá sjást dæmi um að Hæstiréttur leitast einnig við að skýra nánar dómaframkvæmd sína, dregur saman hvers efnis fordæmisreglan er.

\section{Dómari í hæstaréttarmáli skilar sératkvæði}

Pessum fræðum til mikillar örvunar eru sjónarmið um gildi fordæma pegar Hæstiréttur klofnar sem kallað er, einn eða fleiri dómendur skila sératkvæði, enda gera lögin ráð fyrir peim möguleika, sbr. 165. gr. laga nr. 91/1991. Við könnun á gildi fordæma með tilliti til sératkvæða parf pó að rýna vel í hvers eðlis pað er og hvernig dómurinn klofnaði. ${ }^{30}$

Oftar en ekki er aðeins einn dómari í minnihluta og skilar sératkvæði. Með pví verður framlag dómarans af eðlilegum ástæðum persónulegra pví pað er við hann kennt með nafni. Hann er ekki lengur hópsál. Efnistökin og framsetningin getur pví vikið frá íslensku hefðinni en samkvæmt henni er ekki kostur á að hengja forsendur og orðalag peirra á einn frekar en annan í fjölskipuðum dómi. Sama er um hin fjölskipuðu stjórnvöld. Dómari, sem skilar atkvæði í minnihluta og er par ósammála niðurstöðu meirihlutans um pað úrlausnaratriði sem hefur grundvallarpýðingu, er

27 Sjá Sigurður Líndal, Um lög og lögfræði, bls. 280-286.

28 Sjá Sigurður Líndal, Um lög og lögfræði, bls. 221-231 og bls. 246-273 par sem höfundur rekur dæmi um hvernig Hæstiréttur beitir fordæmum, hvernig almennar reglur eru leiddar af dómum, hvernig dómar verða fyrirmyndir annarra dóma, hvenær fordæmum hefur verið hafnað eða pegar vikið er frá peim. Sjá einnig í riti Jóns Steinars Gunnlaugssonar, Um fordæmi og valdmörk dómstóla, einkum umfjöllun í 4. og 6. kafla bókarinnar.

29 Petta er niðurstaða Sigurðar Líndal í könnun hans í ritinu Um lög og lögfræði, sjá bls. 283.

30 Sigurður Líndal, Inngangur að lögfræði II. Réttarheimildir: fordæmi, bls. 63. 
við samningu pess og framlag meðvitaður um að hann leggur ekki pað til málanna sem binda mun aðila í einkamáli. Sá sem er á öndverðum meiði við meirihlutann um refsinæma háttsemi og viðurlög hvorki sakfellir né dæmir refsingu - og hann sýknar ekki ákærða heldur. Niðurstaða meirihlutans stendur.

Eins og fyrr var vikið að má spyrja hvort dómari í hæstaréttarmáli, sem skilar sératkvæði, hljóti ekki að hallast á sveif með meirihlutanum og fylgja fordæmi pegar síðar er dæmt og fordæmið er talið eiga við. Um petta er meðal annars fjallað í grein Jóns Steinars Gunnlaugssonar frá árinu 1992 og áđurnefndu riti hans frá 2003. Nefnir hann nokkra dóma um efnið. Par koma fyrst við sögu hrd. 1987, bls. 362 og hrd. 1987, bls. 373, sem kveðnir voru upp sama dag. Í hinum síðarnefnda voru tveir dómendur sem létu pess getið að peir teldu sig bundna af fyrri úrlausninni um tiltekið atriði, par sem peir voru í minnihluta. Annar lét pessa getið í forsendum meirihluta par sem hann skipaði sér, en hinn í sératkvæði par sem pað tók til annarra atriða. ${ }^{31}$ Í marsmánuði 1991 voru kveðnir upp af Hæstarétti allmargir dómar í hliðstæðum málum par sem til úrlausnar var sakarefni um lögmæti gatnagerðargjalda. Í hrd. 1991, bls. 615 var G gert að greiða umkrafin gatnagerðargjöld, en var sýknaður af kröfunum í héraði. Tveir dómarar Hæstaréttar skiluðu sératkvæði. Annar vildi staðfesta hinn áfrýjaða dóm. Hinn var sammála niðurstöðu meirihlutans, en með öðrum rökstuðningi pó. Pennan dag voru kveðnir upp dómar í 14 öðrum hliðstæðum málum. Vísað var til hins fyrstnefnda um forsendur en sératkvæði dómaranna tveggja voru eðlisólík. Sá sem vildi staðfesta héraðsdóminn skilaði sératkvæði sama efnis. Hinn ítrekaði sératkvæði sitt einnig. Í pessu tilviki voru forsendur meirihluta Hæstaréttar settar fram í fyrsta málinu og svo vísaði sami meirihlutinn til peirra í peim sem á eftir komu. Ástæða pess að dómararnir tveir ítrekuðu sératkvæði sín kann að vera sú að dómarnir allir voru kveðnir upp sama dag. Рað breytir pví pó ekki að hugsanlega hefði verið eðlilegt að peir fylgdu meirihlutanum í peim málum sem á eftir komu. Tilvik sem pessi eru ekki ópekkt. Nefna má dóma er gengu í Hæstarétti 11. mars 1999 en par var úrlausnarefnið hvort greiða ætti fyrrum starfsmönnum Áburðarverksmiðju ríkisins biðlaun. Sömu dómarar greiddu sératkvæði sama efnis í fleiru en einu máli um hliðstæð sakarefni.

\subsection{Sératkvæði hefur áhrif á löggjafann}

Fordæmi hafa orðið til pess að löggjafinn breytti settum lögum. En sératkvæði í dómum hafa einnig haft pau áhrif. Um hið fyrrnefnda eru allmörg dæmi, fordæmi leiða til lagabreytinga og par má nefna réttarfarsbyltinguna á níunda og tíunda áratug síðustu aldar stig af stigi. Einnig má tína til lög nr. 1/1999 um breytingu á lögum um stjórn fiskveiða, sem leiða beinlínis af hrd. 1998, bls. 4076 (veiðileyfamál). ${ }^{32}$ Sama

31 Jón Steinar Gunnlaugsson, Fordæmisgildi hæstaréttardóma, bls. 172-173; sami höfundur, Um fordæmi og valdmörk dómstóla, bls. 27 o.áfr.

32 Alpingistíđindi, 1998-1999 A, pskj. nr. 443, sjá almennar athugasemdir í frumvarpi til breytinga á lögum um stjórn fiskveiða. 
er að segja um breytingu á lögum um almannatryggingar sem beina afleiðingu af hrd. 2000, bls. 4480 (öryrkjamál fyrra).

Sératkvæði með dómi Hæstaréttar hefur haft áhrif á löggjafann með skýrum hætti. Eitt sinn reyndi á hvort ríkið bæri bótaábyrgð ef ekki hefði verið staðið réttilega að lögskráningu sjómanns með peim afleiðingum að lögboðin líf- og slysatrygging reyndist ekki vera fyrir hendi. Féll dómur í Hæstarétti í nóvember 1978 (hrd. 1978, bls. 1186) par sem niðurstaðan varð sú að bótaábyrgðin væri útgerðarmanns, en ekki ríkissjóðs. Lögunum sem pá giltu um lögskráningu sjómanna nr. 63/1961 var breytt og varaábyrgð ríkissjóðs gerð virk. ${ }^{33}$ Í athugasemdum sem fylgdu frumvarpi að breytingalögunum var vísað til niðurstöðu dóms Hæstaréttar og að beðið hefði verið eftir henni. Sérstaklega var pó getið um afstöðu minnihlutaatkvæða tveggja hæstaréttardómara og forsendur peirra teknar sérstaklega upp í athugasemdum með frumvarpinu. ${ }^{34}$ Óhætt er pví að segja að sératkvæðið hafði mikil áhrif á pá lagabreytingu sem gerð var. Hvort einhuga niðurstaða Hæstaréttar um að hafna bótaskyldu ríkissjóðs við pessar aðstæður hefði haft sömu áhrif skal ósagt látið en röksemdir minnihlutans urðu ríkur og afgerandi páttur við lagasetningu. Forsendur í sératkvæði urðu beinlínis að lögskýringargagni. Láti löggjafinn til sín taka að setja sérstakar reglur um hvernig beri að haga aðild ríkisins til varnar vegna stjórnvaldsákvarðana, verður fróðlegt að sjá hvaða sjónarmið úr dóminum frá 18. júní 2008 verða ofan á. Rétt er að líta á nýleg tilvik par sem greidd hafa verið sératkvæði og tekist var á um dómvenju eða fordæmi.

\section{2. Ágreiningur um fordæmi í sératkvæði dómara}

Til eru dæmi um að hæstaréttardómari skili sératkvæði í máli par sem hann lýsir sig í raun ósammála pví fordæmi sem hann telur sér pó skylt að fylgja. Fyrr er getið dóma par sem tekist hefur verið á um mörk eignarlanda og pjóðlendna. Hæstiréttur hafði lagt grunninn að ýmsum grundvallarviðhorfum um sönnun eignarréttar, sönnunarbyrði og gildi margs konar gerninga eða heimilda um landsvæði. Ekki síður lagði Hæstiréttur grunn að pví hvernig túlka bæri ákvæði laga nr. 58/1998 um pjóðlendur og ákvörðun marka eignarlanda, pjóðlendna og afrétta, sérstaklega um pað hvort lögin horfðu til breytinga á reglum um sönnun eignarréttar. Gengu fyrstu dómar Hæstaréttar í svonefndum pjóðlendumálum í októbermánuði 2004 og allmargir árin á eftir, allt par til sératkvæði eins dómara birtist pann 4. október 2007 í málinu nr. 27/2007. Par sagði meðal annars:

Fyrsti úrskurður óbyggðanefndar féll 21. mars 2002. Síðan hafa allmargir úrskurðir hennar gengið og dómsmál risið um gildi peirra. Mál petta var endurupptekið hjá óbyggðanefnd 8. nóvember 2004 og fengu pá lögmenn aðila að tjá sig um fyrstu dóma Hæstaréttar í pjóðlendumálum. Í fyrstu tveimur málum Hæstaréttar af pessu tagi sátu sjö dómarar, en í 1. mgr. 7. gr. dómstólalaga nr. 15/1998 er heimild til að hafa pann háttinn á

33 Lög nr. 24/1980 um breyting á lögum nr. 63/1961 um lögskráningu sjómanna.

34 Alpingistíðindi, 1979-1980 A, pskj. nr. 169, bls. 809-810. 
pegar um sérlega mikilvæg mál er að ræða, sjá dóma Hæstaréttar í málunum nr. 47/2004 og nr. 48/2004, sem kveðnir voru upp 21. október 2004. Í pessum dómum og síðari dómum réttarins, par sem fimm dómarar hafa jafnan skipað dóm, hafa verið lagðar meginlínur við skýringu á helstu atriðum laganna, og einnig meðal annars um pýðingu einstakra tegunda skjala, staðhátta og nýtingar á landi. Pá hafa verið skýrð ýmis eignarréttarhugtök og markaðar sönnunarreglur, en pessi atriði eru til meðferðar í pví máli sem nú er til endurskoðunar. Óbyggðanefnd á enn eftir að taka til meðferðar stór svæði Íslands. Hún hefur á grundvelli dóma Hæstaréttar gefið út „almennar niðurstöður“ sínar sem hún lítur til við úrlausn einstakra mála. Pá hafa héraðsdómarar vísað til efnisúrlausna Hæstaréttar við rökstuðning fyrir niðurstöðum sínum, líkt og héraðsdómari gerir í pví máli sem hér er til úrlausnar. Auk pess hefur rétturinn sjálfur oft vísað til fordæma sinna um einstök atriði, sbr. til dæmis að taka mál nr. 498/2005 og stundum einnig vísað til samræmissjónarmiða pannig að eignastaða tiltekins landsvæðis miðast við eignastöðu aðliggjandi svæðis, sbr. til dæmis mál nr. 48/2004.

Ég tel að í fyrrnefndum dómum Hæstaréttar hafi rétturinn á ýmsan hátt gert strangari kröfur til sönnunarfærslu um eignarréttindi að fasteignum en rétt hefði verið að gera og finna má einnig eldri fordæmi fyrir að áður hafi verið gert. Fordæmi Hæstaréttar er ekki bindandi réttarheimild pótt litið verði til fordæmis við úrlausn máls. Gildi fordæmis felst fyrst og fremst í pví að í fordæminu kemur fram hvernig komist var að niðurstöðu í sambærilegu tilviki á grundvelli skráðra eða óskráðra réttarheimilda. Hins vegar verður ekki hjá pví komist að líta til pess að fordæmi Hæstaréttar í pessum málaflokki hafa verið ítrekuð pað oft í síðari dómum að telja má að dómvenja hafi skapast. Pá felast í jafnræðisreglu 1. mgr. 65. gr. stjórnarskrárinnar kröfur um samræmingu í lagaframkvæmd, en tilgangur laga nr. 58/1998 er eins og áour segir einmitt samræming á eignarréttarlegri stöðu einstakra svæða landsins. Að pessu virtu tel ég að ekki verði hjá pví komist að líta til dóma Hæstaréttar um pau meginatriði sem leggja ber til grundvallar pegar ákveðin eru mörk pjóðlendu og koma við sögu í pessu máli. Af pessum sökum er ég sampykkur niðurstöðu meirihluta dómenda um sýknu stefnda, íslenska ríkisins á kröfum áfrýjenda Guðjóns Stefáns Guðbergssonar og Sigríðar Hjartardóttur.

Bent hefur verið á að pegar dómari kýs að fylgja fordæmi, geri hann pað vegna pess að hann telur sig bundinn af peirri reglu sem dómstóllinn hefur mótað og felst í fordæminu. Breytir pá ekki öllu pótt hann sé í reynd annarrar skoðunar. ${ }^{35}$ Sératkvæði geta verið margbrotin en einfaldast er að skipta peim í tvennt. Annars vegar er viðkomandi dómari eða dómarar ósammála meirihlutanum eða að hann eða peir eru sammála meirihlutanum en með öðrum rökstuðningi. Hvort tveggja getur átt við um úrlausnina í heild sinni eða að hluta. Sératkvæðið hér að framan hrindir í raun pessari tilraun til að skipta sératkvæðum í tvennt með svo einföldum hætti sem reynt var. Dómarinn er í raun sammála meirihlutanum og pegar upp er staðið einnig á sömu forsendum. Hann segir fordæmi ekki bindandi réttarheimild en pað skuli vera til hliðsjónar. Sératkvæðið er greitt með trega en huggunar leitað í jafnræðisreglu 1. mgr. 65. gr. stjórnarskrárinnar. Spyrja má hvaða tilgangi pessi skoðun í sératkvæðinu pjónaði fyrir sakarefni málsins? Var hugljómunin e.t.v. sú að kenningin um fordæmisgildi dóma ætti sér sömu rætur og jafnræðisreglur? Dómarinn hefði einfaldlega getað dæmt með meirihlutanum við svo búið eða gert einfalda athugasemd.

35 Sigurður Líndal, Inngangur að lögfræði II. Réttarheimildir: fordæmi, bls. 219. 
Athugasemdir einstakra dómara í forsendum eru pekktar án pess að um eiginlegt sératkvæði sé að ræða.

Nefna má annað sératkvæði í hæstaréttarmáli par sem tveir dómendur fjölluðu um fordæmi á pann hátt að athygli hlýtur að vekja. Vonandi er ekki slitið úr samhengi pótt aðeins sé tekin upp eftirfarandi tilvitnun í pað (sjá hrd. 10. desember 2007 í málinu nr. 634/2007):

Hvorugur pessara dóma hefur að okkar mati fordæmisgildi um pá lögskýringu sem hér er til meðferðar, par sem í forsendum peirra er ekkert að henni vikið, enda hafði petta álitaefni ekki verið nefnt af hálfu peirra manna sem borið höfðu framsalsúrskurði dómsmálaráðherra undir dóm í peim tilvikum. Teljum við að ekki komi til greina að hæstaréttardómur teljist hafa fordæmisgildi um atriði sem ekki eru borin upp við meðferð máls og koma af peirri ástæðu ekki til sérstakrar umfjöllunar í dómi. Gildir petta jafnvel pó að um kunni að vera að ræða atriði sem dómstólnum ber að gæta af sjálfsdáðum en hefur láðst að gera.

Niðurlagið í pessari tilvitnun er allrar athygli verð. Parna telja tveir dómarar að tiltekin fordæmi hafi ekki gildi par sem úrlausnarefnið er frábrugðið, en virðast pó gefa ótvírætt í skyn að ekkert komi í veg fyrir að Hæstiréttur eigi að hafa fullt frelsi til að endurskoða eigin fordæmi. Eins og bent var á hafa fallið dómar par sem fyrri niðurstöðum er gagngert snúið við að óbreyttum settum lögum. Рað hefur hins vegar oftar komið til undir ýmsum áhrifum, breyttum áherslum við skýringu stjórnarskrár, fulltingi pjóðréttarlegra skuldbindinga og dómaframkvæmdar alpjóðadómstóla svo sem Mannréttindadómstóls Evrópu og áður Mannréttindanefndar. Peir dómar sem hér eru hafðir í huga eru hrd. 1990, bls. 2, hrd. 1995, bls. 1444 og hrd. 2001, bls. 3451 $(129 / 2001)$.

\subsection{Dómari í minnihluta situr fast við sinn keip}

Fyrr eru nefnd dæmi pess og viðhorf um að dómari í minnihluta telji sig síðar bundinn af fordæmi pví sem meirihluti stóð að. En pað er ekki alltaf svo eins og dæmin sanna. Í dómi Hæstaréttar frá 23. október 2008 í málinu nr. 491/2007 var til endurskoðunar sakfelling héraðsdóms fyrir brot á áfengislögum. Byggði sakfellingin á pví að ákærði hefði sem ritstjóri blaðs bakað sér refsiábyrgð samkvæmt 20. gr., sbr. 27. gr. áfengislaga nr. 75/1998 með pví að áfengisauglýsingar voru birtar í blaðinu. Var refsiábyrgðin lögð á ákærða sem ritstjóra á grundvelli 15. gr. laga nr. 57/1956 um prentrétt. Málið dæmdu fimm dómendur. Hæstiréttur tók afstöðu til peirra varna ákærða að refsiákvæði áfengislaga brytu í bága við 73. gr. stjórnarskrár um tjáningarfrelsi, sbr. 10. gr. Mannréttindasáttmála Evrópu. Einnig purfti að leysa úr peirri viðbáru ákærða að jafnræðisregla stjórnarskrár gæti ekki umborið pá skipan laga að áfengisauglýsingar fengju að birtast almenningi óáreittar í erlendum tímaritum í skjóli undantekningarákvæða 20. gr. áfengislaga. Hæstiréttur tók afstöðu til pessara varna með ítarlegum rökstuðningi par sem meðal annars var getið fordæma réttarins. Var nefndur dómur Hæstaréttar frá 1999 par sem ákvæði áfengislaga voru metin gagn- 
vart tjáningarfrelsisákvæðum æðri laga. ${ }^{36}$ Pá var vísað til hæstaréttardóms frá 14. júní 2007 (599/2006) hvað snerti skuldbindingar íslenska ríkisins vegna EES-samningsins. Um jafnræðisreglu stjórnarskrárinnar og vörnum á henni byggðum vísaði meirihluti Hæstaréttar til hrd. 2006, bls. 1689 (220/2005) par sem skorið var úr um pað hvort bann við auglýsingum á tóbaki samkvæmt 7. gr. laga nr. 6/2002 um tóbaksvarnir væri andstætt almennri jafnræðisreglu vegna fráviks frá auglýsingabanni, samkvæmt 1. mgr. 7. gr. laganna um tóbaksauglýsingar í erlendum ritum. Taldi Hæstiréttur pá undantekningu hliðstæða peirri sem væri í 1. tölulið 4. mgr. 20. gr. áfengislaga. Efnislega taldi meirihlutinn að vörn ákærða um að jafnræði yrði raskað með fráviki frá banni við áfengisauglýsingum væri efnislega hin sama og pegar hefði verið skorið úr um varðandi frávik frá banni við tóbaksauglýsingum. Málsvörn ákærða, sem á pessu var reist, var hafnað. Pá nefndi meirihlutinn einnig að pótt aðrir hefðu komist upp með háttsemi, sem fæli í sér brot gegn banni við auglýsingum á áfengi, gæti pað ekki leitt til pess nú frekar en endranær að lögbrot annarra geri sambærilega háttsemi pess sem sætir ákæru refsilausa af peim sökum. Dómur Hæstaréttar í pessu máli var skipulega studdur nýlegum fordæmum og forsendur meirihlutans hafa öll einkenni pess að vera einnig stefnumarkandi fordæmi.

Einn dómenda var niðurstöðunni hins vegar ósammála og taldi að ástæður lægju til pess að ekki skyldi gera ákærða refsingu fyrir pá háttsemi sem honum væri gefin að sök. Par er á sannfærandi hátt varpað fram ýmsum staðreyndum sem gögn málsins endurspegluðu um pað hversu áfengisauglýsingar- og kynningar voru allt um kring, ýmist óáreittar af ákæruvaldinu eða í skjóli peirrar lögboðnu undantekningar að hin almenna bannregla skyldi ekki útiloka landið frá dreifingu erlendra tímarita. Um petta sagði dómarinn meðal annars:

Í hæstaréttarmáli nr. 648/2006, sem dæmt var 14. júní 2006, var fjallað um ætlað brot gegn auglýsingabanni 20. gr. áfengislaga. Hinn ákærði hafði par meðal annars varist á peirri forsendu að með nefndum ákvæðum 20. gr. væri brotið væri [sic]gegn jafnræðisreglu 65. gr. stjórnarskrárinnar. Hæstiréttur sýknaði ákærða af öðrum ástæðum. Í forsendum Hæstaréttar sagði allt að einu svo: „Með skírskotun til forsendna héraðsdóms er fram komið að birting auglýsingar peirrar sem um getur í ákæru var andstæð 20. gr. áfengislaga.“ I f forsendum héraðsdómsins hafði verið komist svo að orði um pað atriði sem hér er til umræðu: „Pá liggur fyrir pað mat löggjafans að næsta vonlaust væri að banna allan innflutning á erlendum blöðum og tímaritum par sem áfengisauglýsingar væru birtar eða láta fjarlægja auglýsingar úr innfluttum tímaritum. Er staða ákærða og erlendra aðila ekki sambærileg um petta, en pað er skilyrði fyrir beitingu ákvæðis 65. gr. stjórnarskrárinnar að hún taki til einstaklinga eða lögaðila í sömu stöðu.“ Í pessum forsendum er að mínum dómi rökvilla. Ef svo stendur á að löggjafinn getur ekki komið fram viljaafstöðu sinni um tiltekið málefni með setningu laga, án pess að brjóta gegn rétti borgara til jafnræðis sem nýtur sérstakrar verndar í stjórnarskrá, tel ég afleiðinguna vera pá að alls ekki sé unnt að koma viljaafstöðunni fram með lagasetningu. Ekki er með nokkru móti unnt að nota röksemdina um erfiðleika á að láta borgara njóta jafnræðis til pess að réttlæta misrétti. Ef löggjafinn telur ekki unnt að tryggja borgurum jafnræði við lögfestingu á undanpágu frá tjáningarfrelsi hlýtur afleiðingin einfaldlega að verða sú að undanpága telst óheimil.

36 Sjá hrd. 1999, bls. 781 (415/1998). 
Pá tók dómarinn einnig afstöðu til pess hvort hrd. 2006, bls. 1689 (220/2005) gerði út um pá vörn að ójafnræði fælist í pví að heimila áfengisauglýsingar í erlendum tímaritum. Taldi dómarinn að ekki yrði séð að í forsendum pess dóms hafi verið fjallað sérstaklega um sjónarmið sem að pessu lytu pó að hitt væri rétt að málsástæðunni hafi verið hafnað. Taldi dómarinn að pegar af peirri ástæðu hefði dómurinn ekki fordæmisgildi fyrir pað mál sem til úrlausnar væri. Pessa vörn tók dómarinn pví til sérstakrar skoðunar með pessum orðum:

Að öðru leyti tekur meirihlutinn undir tilgreindan málflutning af hálfu ákæruvalds pegar pessari málsvörn ákærða er hafnað. Sá málflutningur lýtur einkum að pví, að frávikið verði að teljast eðlilegt og pað raski ekki meginmarkmiði bannsins, eins og komist er að orði. Pá megi ætla að rit á erlendum tungumálum eigi ekki jafn greiða leið að börnum og ungmennum eins og efni á íslensku. Ég tel petta ekki geta réttlætt pá mismunun sem hér um ræðir. Börn og ungmenni eiga aðgang að erlendum blöðum og tímaritum rétt eins og peir sem eldri eru. Auk pess eru áfengisauglýsingar birtar í öðrum fjölmiðlum svo sem sjónvarpi, sem telja má að séu mun áhrifameiri gagnvart börnum en erlend blöð. Par eru slíkar auglýsingar meðal annars birtar í tengslum við dagskrárefni sem börn og unglingar fylgjast mikið með svo sem ípróttaefni.

Dómarinn taldi pví að í texta 20. gr. áfengislaga fælist brot gegn jafnræðisreglu, sem nyti verndar samkvæmt 73. gr. og 65. gr. stjórnarskrár og að ákvæðið gæti pví ekki talist refsiheimild að pví er varðar pá háttsemi sem ákærða var gefin að sök. Í atkvæði hans var einnig tekin afstaða til peirrar málsvarnar hversu ótt og títt aðrir hefðu komist upp með pá háttsemi sem honum skyldi refsað vegna. Sá hluti sératkvæðisins er athyglisverður:

Fallast má á að pað geti að öllum jafnaði ekki verið málsvörn í refsimáli að aðrir hafi brotið af sér og komist upp með pað. Í pessu máli eru aðstæður hins vegar afar sérstakar. Með gögnum peim sem ákærði hefur lagt fram hefur hann sýnt fram á að aðrir en hann hafa í stórum stíl komist upp með sambærileg ætluð brot og hann er saksóttur fyrir án pess að lögregla eða ákæruvald hafi brugðist við. Ákærði vísar í pessu efni meðal annars til auglýsinga Áfengis- og tóbaksverslunar ríkisins, sem lýst var í II kafla að framan, og enginn vafi er á að brjóta gegn texta 20. gr. áfengislaga. Í öllum peim tilvikum sem ákærði nefnir er málum svo háttað, að ætluð brot liggja fyrir í útgefnum blöðum og tímaritum. Рað eiga pví af peim sökum varla að vera vandkvæði á að upplýsa pau svo draga megi pá sem að standa til ábyrgðar, rétt eins og ákærða. Verður ekki betur séð en bann áfengislaga við birtingu áfengisauglýsinga sé svo gott sem marklaust par sem svo margir brjóta gegn pví, að pví er virðist daglega, án pess að brugðist sé við af hálfu peirra sem halda eiga uppi refsivörslu í landinu. Meðal peirra sem brjóta gegn banninu er eins og fyrr var greint sjálft íslenska ríkið við rekstur einkasölu á áfengi í ÁTVR.

Við mat á pví hvort menn njóti jafnræðis gagnvart öðrum verður að mínu mati ekki með öllu litið fram hjá pví hvernig refsivörslu á viðkomandi sviði er háttað. Lögin geta ekki lifað í tómarúmi. Ef framkvæmd peirra er með peim hætti að mönnum er mismunað í reynd á jafn grófan hátt og hér um ræðir er í raun og veru verið að refsa einum fyrir pað sem yfirleitt er látið átölulaust hjá öðrum. Pegar svo rammt kveður að pessu sem raunin er í pví máli sem hér er til úrlausnar tel ég að refsingu verði ekki við komið. Pessi ástæða ætti að mínu áliti að minnsta kosti að leiða til pess að ákærða yrði ekki gerð refsing fyrir pá háttsemi sem honum er gefin að sök. 
Hæstiréttur kvað mjög stuttu síðar upp annan dóm par sem leyst var úr ákæruatriðum sem reist voru á pví að brotið hefði verið gegn 20. gr. áfengislaga. Ákærðu voru ritstjórar tveir. Dómur Hæstaréttar féll 6. nóvember 2008 í málinu nr. 143/2008. Málið dæmdu prír hæstaréttardómarar, p.á m. sami dómarinn og greitt hafði sératkvæðið sem rýnt var í. Til úrlausnar voru mannréttindaákvæði stjórnarskrár og í dómi Hæstaréttar sagði:

Hæstiréttur hefur komist að peirri niðurstöðu að bann við áfengisauglýsingum brjóti hvorki gegn 73. gr. stjórnarskrárinnar né skuldbindingum íslenska ríkisins samkvæmt samningnum um Evrópska efnahagssvæðið, sem hefur lagagildi með lögum nr. 2/1993. Um petta vísast til dóma réttarins í máli nr. 415/1998 á bls. 718 í dómasafni réttarins 1999, dóms í máli nr. 599/2006, sem kveðinn var upp 14. júní 2007, og dóms í máli nr. 491/2007, sem kveðinn var upp 23. október 2008.

Í málinu var einnig tekist á um skýrleika refsiheimilda með hliðsjón af ákvæðum laga um prentrétt, sem ástæðulaust er að reifa sérstaklega, en einn dómenda galt sératkvæði. Hann reifaði sératkvæði sitt í málinu frá 23. október sem fyrr er getið og taldi að í málinu ættu við öll sömu sjónarmið og grein var gerð fyrir par. Nefndi hann sérstaklega að fyrir lægi að meirihluti Hæstaréttar í pví máli hefði verið annarrar skoðunar um gildi refsiheimildarinnar, tilvitnuð lagaákvæði hefðu par verið talin standast ákvæði stjórnarskrár og peim beitt sem heimild til ákvörðunar refsingar í málinu. Dómarinn tók til sérstakrar skoðunar hvort sú niðurstaða væri bindandi fyrir Hæstarétt, og eftir atvikum einstaka dómara við réttinn í síðari málum par sem reyndi á hliðstætt sakarefni og pá á grundvelli fordæmisreglu sem felist í dóminum. Um petta sagði dómarinn:

Рað er skoðun mín að fordæmi sé ekki sjálfstæð réttarheimild, sem dómstólum sé skylt að beita án tillits til peirrar réttarheimildar sem leiddi til niðurstöðunnar. Ég tel að fordæmi sé frekar afleidd heimild sem sé aðeins jafn bindandi og sú réttarheimild sem fordæmið byggist á. Dómstólar hafa ekki að réttum stjórnlögum vald til að setja lagareglur. Peirra hlutverk er að finna pær réttarheimildir sem í gildi voru á peim tíma sem málsatvik urðu og leiða af peim reglur sem beitt er við dómsúrlausn, sbr. 61. gr. stjórnarskrárinnar. Á pað jafnt við um sett lög sem aðrar réttarheimildir. Pó að Hæstiréttur komist pannig að ákveðinni niðurstöðu um beitingu réttarheimildar í tilteknu máli hefur pað að mínum dómi ekki pá pýðingu að til hafi orðið ný lagaregla sem upp frá pví sé skylt að beita í sambærilegum málum á sama hátt og skylt er að beita lögum sem stafa frá löggjafanum. Prátt fyrir petta kann að vera nauðsynlegt vegna sjónarmiða um jafnræði manna og samræmi í dómsúrlausnum að taka mið af fyrri úrlausnum Hæstaréttar pegar leyst er úr máli. Verður dómari að vega pessi sjónarmið saman pegar á reynir.

Í pessu máli er um að ræða sakarefni sem varðar að mínum dómi brot gegn stjórnarskrárvörðu tjáningarfrelsi og jafnræði borgara, sbr. 65. og 73. gr. stjórnarskrár. Tel ég brot bæði felast beinlínis í ákvæðum settra laga og einnig í framkvæmd laga svo sem lýst var í nefndu sératkvæði í máli nr. 491/2007. Að auki er hér um að ræða refsimál en stjórnarskráin hefur að geyma ákvæði í 69. gr. sem felur í sér sérstakar kröfur til skýrleika laga sem heimila refsingu. Við pessar aðstæður hlýt ég að komast að sömu niðurstöðu og í máli nr. 491/2007. Ber pví að mínum dómi að sýkna ákærðu og leggja sakarkostnað vegna meðferðar málsins í héraði og fyrir Hæstarétti á ríkissjóð. 
Í pessum tveimur málum er sami dómari með sératkvæði og heldur fast við sitt. Í fyrra málinu dæmdu fimm dómarar en í hinu síðara prír. Sami dómari skilar sératkvæði í báđum málunum. Í hinu síðara eru hinir tveir ekki á meðal peirra sem dæmdu í fyrra málinu. Dómarinn sem skilar sératkvæðinu telur fordæmi ekki bindandi réttarheimild og getur pess sérstaklega í síðara málinu. Best hefði verið að láta pess ógetið að í hlut á höfundur bókarinnar um fordæmi og valdmörk dómstóla frá árinu 2003 en pað skiptir ekki öllu. Annars vegar á í hlut fræðimaður og hins vegar dómari. Pessi mörk verður að virða en ekkert mælir gegn pví að bregða mælistiku bókarinnar á sératkvæðið. Sú skoðun kemur berum orðum fram í sératkvæði dómarans að dómstólar hafi ekki vald til að setja lagareglur. Рað má hins vegar velta pví upp hvort pað að skila sératkvæði pessa efnis og gagnvart fyrri fordæmum sýni vilja til að auka hlutverk dómstóla við lagasetningu. Pessu er haldið fram sökum pess að annars hefði dómarinn átt að vera sammála meirihlutanum og við svo búið varpað pví til löggjafans hvort breyta ætti lögum. Fordæmið var komið fram um pað lagaatriði sem á reyndi. Fordæmið var nýtt og pótt rétturinn hefði klofnað hið fyrra sinn var aðeins einn dómari af fimm sem skilaði sératkvæði.

Höfundur bókarinnar hafnar pví ítrekað að til séu fleiri en ein mismunandi en jafn réttar niðurstöður. ${ }^{37}$ Í sama riti kemur fram að ekki sé útilokað að minnihluti í sjö manna dómi geti síðar myndað meirihluta fyrir niðurstöðu sinni með dómara eða dómurum sem ekki áttu sæti í sjö manna dóminum. Hins vegar megi almennt ætla að dómarar, sem eru í minnihluta innan réttarins um ákveðna niðurstöðu, muni beygja sig fyrir fordæminu, einkum ef peir vita að hreinn meirihluti er meðal dómara við réttinn fyrir pví. ${ }^{38}$ Áður er minnst á hvernig hugmyndin um gildi fordæma er sett fram í pví riti. Par er gerður fyrirvari um pýðingu fordæmis ef meðferð réttarheimildarinnar, sem réði niðurstöðunni í pað skiptið, hafi verið röng. Dómarinn var vitaskuld á engan hátt bundinn af pví sem hann hafði áđur ritað um á vettvangi fræðanna. Og pegar borið er niður í riti hans, meðal annars pví sem rakið er fyrr, er ekki að sjá að sératkvæðið geymi einhverjar pversagnir miðað við fræðiskrifin. Pað hljóta pó að vakna álitamál um pað hversu pað samræmist kenningunni um hina einu réttu lögfræðilegu niðurstöðu að dómari hafni svo nýlegu og afgerandi fordæmi. Ef til vill fer pað allt eftir pví hvernig menn skilja orðin „ein rétt niðurstaða“, hvenær er hún rétt og hvenær var önnur niðurstaða röng? Átti dómarinn að beygja sig undir fordæmi meirihlutans? Meirihlutans í fyrra málinu og meirihlutans í seinna málinu?

Sakfelling ritstjórans með dóminum frá 23. október 2008 hefur að líkindum verið honum pungbær en eflaust var pað honum til einhverrar sáluhjálpar að einn dómenda við Hæstarétt teldi á honum brotið vegna grundvallarréttinda hans sem ættu stoð í stjórnarskrá lýðveldisins. Ekki skal fullyrt hvaða skoðun pessi sami ritstjóri hefur haft á síðara málinu par sem kollegar hans hlutu sömu örlög, sakfellingu og refsingu. Einhver hefði a.m.k. talið sálu sinni enn betur borgið í pað skiptið pegar

37 Sjá t.d. bls. 38-39 í ritinu.

38 Sjá bls. 70 í nefndu riti. 
enn var skilað sératkvæði. En pað er ekki óhugsandi að sams konar ákæru- og lagaatriði komi á ný fyrir Hæstarétt. Aftur yrði tekist á um stjórnarskrárákvæðin í pví samhengi. Atvikin eru í öllum meginatriðum sams konar en aftur væri tekist á um lagaatriðið - réttarheimildina. Hugsanlega verða pá prír dómarar, sá sem skilaði sératkvæðunum og einn eða tveir aðrir en dæmt höfðu áður. Túlkun peirri sem haldið var á lofti í sératkvæðum yrði aflað fylgis við málflutning allan og viðkomandi sýknaður. Enn skulu ritstjóranum gerðar upp skoðanir eða viðhorf. Var hann frumkvöðullinn sem bar krossinn fyrir hina eða renna á hann tvær grímur og verður hann e.t.v. ekki jafn pakklátur líknara sínum og ætla mætti? Stofnunin var Hæstiréttur Íslands, sá hinn sami og dæmdi hann en sýknaði annan að óbreyttum lögum og stjórnlögum.

Pegar pessi sératkvæði eru borin saman við hvernig Hæstiréttur klofnaði í málinu um aðild íslenska ríkisins í dóminum frá 18. júní 2008, sést við nánari athugun að í báðum tilvikum er viðfangsefnið hvort meðferð réttarheimilda í fyrri dómsúrlausnum hefði verið rétt eða röng. Рað á ekki bara við um sératkvæði dómendanna tveggja sem mynduðu minnihlutann, heldur líka hinna. Dómararnir prír sem stóðu að niðurstöðu meirihlutans - einn peirra með öðrum forsendum - voru að taka fyrri dómaframkvæmd til endurskoðunar. Peir túlkuðu við pá athugun lög sem ekkert höfðu breyst.

\section{Niðurlag}

Dómurinn sem nefndur var í upphafi vakti athygli höfundar á pví að sú staða kemur upp að löggjafinn parf að leysa úr réttaróvissu sem segja má að dómsvaldið eigi upptökin að. Hæstiréttur tekst á við fordæmi sín, rétturinn príklofnar og dómendur túlka fyrri fordæmi með ólíkum hætti, berja jafnvel eitthvað í brestina til að renna stoðum undir fyrri niðurstöðu. Ákallið til löggjafans birtist oftar - a.m.k. ópægilega oft - í pví að lög hafa ekki staðist gagnvart stjórnarskrá og að gera varð á peim breytingar. Par hefur jafnræðisregla stjórnarskrár komið við sögu á afgerandi hátt. Hér er átt við dómana sem leiddu óhjákvæmilega af sér breytingar á lögum um stjórn fiskveiða og um almannatryggingar. Dómar af sama meiði geta einnig valdið pví að ekki verður byggt á lögum með sama hætti aftur - peim yrði pá aftur vikið til hliðar og réttindi eða réttarstaða kræf án tillits til peirra.

Í sératkvæðinu sem fylgdi seinni dóminum um ákæruatriði vegna áfengisauglýsinga var hins vegar skoðun dómarans sú að pótt Hæstiréttur kæmist að niðurstöðu um beitingu réttarheimildar í tilteknu máli hefði pað ekki pá pýðingu að til hefði orðið ný lagaregla sem upp frá pví væri skylt að beita í sambærilegum málum á sama hátt og skylt er að beita lögum sem stafa frá löggjafanum. Sagði dómarinn síðan: „Prátt fyrir petta kann að vera nauðsynlegt vegna sjónarmiða um jafnræði manna og samræmi í dómsúrlausnum að taka mið af fyrri úrlausnum Hæstaréttar pegar leyst er úr máli. Verður dómari að vega pessi sjónarmið saman pegar á reynir." 
Í dóminum sem nefndur var um pjóðlendumörk frá 2007 gekk einn dómari út frá pví að fordæmi hefðu verið ítrekuð svo oft að komin væri á dómvenja og vísaði hann til 65. gr. stjórnarskrárinnar. Í hinu tilvikinu, um brot gegn 20. gr. áfengislaga, gerir dómarinn jafnræðisregluna að eins konar varnagla en nefnir að vega verði pau sjónarmið saman pegar á reyni. Spyrja má hvort ekki hafi verið komin fram dómvenja eða a.m.k. skýr fordæmi um gildi refsiheimildarinnar um brot við áfengisauglýsingum gagnvart æðri lögum, rétt eins og meirihlutaákvæðin bera með sér. Sératkvæðið hið síðara í málum ritstjóranna tveggja hlýtur að teljast býsna markvert fyrir pær sakir að málið var dæmt aðeins tæpum tveimur vikum eftir að starfsbróðir peirra hlaut sinn dóm. Hinu má ekki gleyma að dómarinn sem stóð að sératkvæðinu var ekki bara að vega og meta áhrif jafnræðisreglu, hugsanlega stjórnarskrár, heldur var hann líka að túlka hana og önnur ákvæði stjórnarskrár í samhengi við gildi refsiheimildarinnar. Hugsanlega taldi hann rétt af peim ástæðum að halda sig við afstöðu sína og að fyrra fordæmi væri ekki rétt túlkun réttarheimilda. Hann virðist líta svo á að meðferð réttarheimilda og túlkun peirra í dómsniðurstöðu hins fyrra máls hafi verið röng. Er slík afstaða í mótsögn við pað sjónarmið að hafna beri pví að fleiri en ein rétt niðurstaða sé til um sama sakarefnið að óbreyttum lögum? Рað parf ekki að vera. Dómarinn taldi sig leita að hinni einu réttu niðurstöðu og hafnaði fordæminu. Og pá má spyrja hvort hin eina rétta lögfræðilega niðurstaða sæti huglægu mati. Ef svo er verður hún ekki einmana mjög lengi. Fordæmið sem dómarinn hafnaði hlaut að vera sterkt og áhrifaríkt enda stóðu að pví fjórir dómarar af fimm. Var pað ekki sú réttarheimild sem hlaut að vera afgerandi í leitinni að hinni einu réttu niðurstöðu? Almennt sýna dómarnir sem reifaðir voru að framan að afar mikið parf til að koma ef Hæstiréttur víkur frá nýlegu fordæmi um stefnumarkandi skýringu á stjórnarskrá. Nefndar voru í dæmaskyni úrlausnir um ákvæði skaðabótalaga annars vegar og hins vegar skerðingu lífeyrisgreiðslna gagnvart stjórnarskrá. Í forsendum meirihluta Hæstaréttar um ákvæði 20. gr. áfengislaga gagnvart æðri heimildum kveður við sama tón.

Dómstólar beita jafnræðisreglum og hún höfðar til manna. Stjórnvöld eru í úrlausnum sínum bundin við jafnræðisreglu stjórnsýslulaga. Jafnræðisregla stjórnarskrárinnar heldur löggjafanum við efnið sem og öðrum. Í réttarfarinu er jafnræðisregla einnig orðuð sem ein af meginreglum á pví sviði. Henni er fremur ætlað að jafna tækifæri aðila við málarekstur fremur en að afla peim réttinda. Og pá er rétt að varpa peirri spurningu fram hvort jafnræðisregla stjórnarskrárinnar bindi hendur dómsvaldsins sérstaklega, ekki bara um pað augljósa, að henni verði beitt við úrlausn máls, heldur einnig hvort dómstólar verði að fara eftir henni við beitingu dómsvalds. Og hér er pá aðeins átt við pá réttarheimild sem í fordæminu felst. Á einhvern hátt varð hún til með fordæminu, p.e. dóminum. Minnast ber pess enn að flestir aðhyllast pá kenningu að í raun sé Hæstiréttur ekki bundinn af fordæmum sínum. En dómsvaldið er einn páttur ríkisvalds og ákvæði stjórnarskrárinnar binda eftir atvikum alla pessa prjá pætti pess. Hún leggur kvaðir á dómsvaldið, t.d. eins og kveðið er á um í 
61. gr. og 70. gr. hennar. Er pað framsækin skýring að 65. gr. stjórnarskrárinnar leggi pá skyldu á herðar dómsvaldinu að fylgja fordæmum?

Í greinargerð með frumvarpi að stjórnarskipunarlögum kemur fram að pótt jafnræðisreglan hafi ekki áđur verið bundin í stjórnskipunarlög með skýrum hætti hafi engu að síður verið litið svo á að hún væri ein helsta undirstaðan í íslenskri stjórnskipun og almennt í íslenskum rétti. Í henni væru e.t.v. ekki fólgin ákveðin efnisréttindi en mikilvægi hennar fælist ofar öllu í pví að vera almenn leiðbeiningarregla. ${ }^{39}$ Í 11. gr. stjórnsýslulaga nr. 37/1993 er mælt fyrir um bann við að mismuna aðilum við úrslausn mála í stjórnsýslunni. Varpa má pví fram hvort 65. gr. stjórnarskrárinnar gerir ekki sambærilegar kröfur til dómsýslunnar. Hæstiréttur hefur sjálfur talið að mannréttindaskuldbindingar og mannréttindaákvæði stjórnarskrárinnar geri tilteknar kröfur til dómstóla. Sagði t.d. í hrd. 1995, bls. 1444 að fallast yrði á „, .. að staða dómarafulltrúa, eins og henni er nú fyrir komið, uppfylli ekki grunnreglur stjórnarskrár um sjálfstæði dómsvaldsins, svo sem pær verða skýrðar með hliðsjón af 1. mgr. 6. gr. Mannréttindasáttmála Evrópu um sjálfstæða og óvilhalla dómara ..." Pá má einnig nefna í dæmaskyni hrd. 2000, bls. 4394 (419/2000) par sem horft var fram hjá peim lögmæltu takmörkunum á rétti föður til að höfða faðernismál á pann hátt sem gert var í barnalögum. Var niðurstaða Hæstaréttar sú að takmörkunin bryti gegn 70. gr. stjórnarskrárinnar, sbr. einnig 6. gr. Mannréttindasáttmála Evrópu. Ekki voru fyrir hendi nægar málefnalegar forsendur til peirrar mismununar sem birtist í reglum barnalaga um málsaðild í faðernismálum. Í málinu rökstuddi Hæstiréttur pessa niðurstöðu ítarlega með stuðningi í 70. gr. og 65. gr. stjórnarskrár, sem og ákvæðum Mannréttindasáttmála Evrópu sem lögfestur hafði verið. Um jafnræðisregluna sagði Hæstiréttur sérstaklega:

Í 65. gr. stjórnarskrárinnar, par sem kveðið er á um að allir skuli vera jafnir fyrir lögum og njóta mannréttinda, er sérstaklega áréttað í 2. mgr. að konur og karlar skuli njóta jafns réttar í hvívetna. Sams konar bann við mismunun birtist í 14. gr. Mannréttindasáttmála Evrópu, sbr. lög nr. 62/1994. Í athugasemdum með frumvarpi að stjórnskipunarlögum nr. 97/1995 kom fram að í jafnræðisreglu 65. gr. stjórnarskrárinnar væru ekki fólgin ákveðin efnisréttindi, heldur fælist mikilvægi hennar fyrst og fremst í pví að henni væri ætlað að vera almenn leiðbeiningarregla um bann við mismunun, sem beri ávallt að hafa að leiðarljósi, ekki einvörðungu við setningu laga, heldur og við skýringu peirra.

Í pessum málum sem nefnd voru í dæmaskyni, var ákvæðum stjórnarskrár beitt um pær kröfur sem gera verður til dómsvaldsins. Hvort sem um var að ræða stöðu dómarafulltrúa, eins og henni var háttað, eða ákvæði um málsaðild í faðernismálum pá vörðu sakarefnin pær kröfur sem gera varð til laga um dómstólaskipanina og aðgang að dómstólum. Lagaframkvæmdin eða löggjöfin sjálf var ekki talin standast. Stjórnarskráin gerir pannig tilteknar kröfur til pessa valdpáttar sem nefnt er dómsvald og dómsvaldið sjálft verður að hlúa að peim kröfum.

39 Alpingistídindi, 1994-1995 A, pskj. nr. 389, bls. 2085. 
Í nokkrum dómum, sem nefndir voru fyrr, koma fram í atkvæðum dómenda vangaveltur um gildi fordæma. Jafnræðisregla svífur par yfir vötnum. Í sératkvæðinu sem fylgdi hrd. frá 4. október 2007 (27/2007) kom fram að í pjóðlendumálum hefðu fordæmi Hæstaréttar verið ítrekuð pað oft í síðari dómum að telja mætti að dómvenja hefði skapast. Vísaði dómarinn pá til 1. mgr. 65. gr. stjórnarskrárinnar sem gerði kröfur um samræmingu í lagaframkvæmd og að tilgangur pjóðlendulaganna væri einmitt samræming á eignarréttarlegri stöðu einstakra svæða landsins. Hann taldi pví ekki verða komist hjá að líta til dóma Hæstaréttar um pau meginatriði sem leggja beri til grundvallar pegar ákveðin væru mörk pjóðlendu og eignarlanda í málinu. Petta niðurlag í sératkvæði dómarans sýnist verða að skýra svo að hann hafi ekki aðeins lagt áherslu á að löggjöfin um ákvörðun pjóðlendumarka og stjórnsýslan um pá framkvæmd gerðu ekki mannamun. Hann virðist beinlínis leggja til grundvallar að dómsvaldið verði að gæta pessa jafnræðis í úrlausnum sínum, við svo búið að dómvenja hafi skapast.

Fordæmi teljast til réttarheimilda. Pau renna styrkari stoðum undir beitingu laga og réttarreglan sem mótuð er verður traustari. Dómstólar móta líka réttarreglur úr öðrum réttarheimildum en stjórnarskrá og settum lögum - slá fastri venju, skýra vægi pjóðréttarskuldbindinga, beita meginreglum laga og eðli máls. Í peim tilvikum einnig gerir fordæmið réttarheimildina sterkari á viðkomandi sviði og menn og stjórnvöld sjá betur fyrir um réttindi, heimildir eða skyldur. Hér verður peirri skoðun lýst að löggjafinn sé betur til pess fallinn að móta nýjar, almennar réttarreglur. Pað er vitað að pær kunna að purfa skýringa við og taka ekki á öllum tilvikum. Til peirra verka eru dómstólar bestir, pegar átök eru og ágreiningur utan réttar. En pað virðast vera átök innan Hæstaréttar um fordæmisgildi dóma og eflaust munu margir hafa mismunandi skoðanir par á. Kenningin um fordæmisgildi dóma byggir meðal annars á pví að samræmis skuli gætt. Ekki er líklegt að menn myndu játast undir pá tillögu að fordæmi yrði með lögum gert að bindandi réttarheimild. Svo flókin og vandmeðfarin hefur jafnræðisreglan verið að trauðla myndu menn heldur vilja finna réttarheimildinni fordæmi beina stoð í 65. gr. stjórnarskrárinnar - pannig að bindandi væri. Jafnræðisreglan er pó greinilega samviska hins íhaldssama dómara og pess framsækna.

\section{Um höfundinn}

Einar Karl Hallvarðsson er dósent við Háskólann á Bifröst og hefur starfað sem lögmaður við embætti ríkislögmanns. Hann fékk réttindi til málflutnings fyrir héraðsdómi árið 1994 og fyrir Hæstarétti árið 1997. Netfang: einarkarl@bifrost.is.

\section{Heimildaskrá}

Ármann Snævarr. Almenn lögfræði. Reykjavík: Orator, 1989.

Einar Karl Hallvarðsson. „Hvernig er petta með ríkið?“ Úlfljótur 58 (2005), bls. 495-525. 
Jón Steinar Gunnlaugsson. „Fordæmisgildi Hæstaréttardóma.“ Tímarit lögfræðinga 42 (1992), bls. 172-176.

Jón Steinar Gunnlaugsson. Um fordæmi og valdmörk dómstóla. Reykjavík: Háskólinn í Reykjavík, 2003.

Sigurður Tómas Magnússon. „Aðgangur að dómstólum á sviði einkamála.“ Tímarit lögfræðinga 55 (2005), bls. 133-182.

Sigurður Líndal. Inngangur að lögfræði. II. Réttarheimildir: fordæmi. Bráðabirgðaútgáfa til kennslu. Reykjavík, 1996.

Sigurður Líndal. Um lög og lögfræði: grundvöllur laga - réttarheimildir. 2. útgáfa. Reykjavík: Hið íslenska bókmenntafélag, 2003.

Skúli Magnússon. „Er pörf á lagasetningu um ađild hins opinbera í dómsmálum?“ Úlfljótur 58 (2005), bls. 527-538.

Ólafur Jóhannes Einarsson. „Réttarfarsskilyrði til að fá stjórnvaldsákvörðun endurskoðaða fyrir dómi." Tímarit lögfræðinga 57 (2007), bls. 39-81.

Pór Vilhjálmsson. „Fordæmi.“ Tímarit lögfræðinga 42 (1992), bls. 168-171. 